\title{
Strontium-90 Liquid Concentration Solubility Correlation in the Hanford Tank Waste Operations Simulator
}

T. M. Hohl, D. E. Place, and R. S. Wittman.

CH2M HILL Hanford Group, Inc.

Richland, WA 99352

U.S. Department of Energy Contract DE-AC27-99RL.14047

$\begin{array}{ll}\text { EDT/ECN: } 821074 & \text { UC: } \\ \text { Cost Center: } 7 \mathrm{G} 410 & \text { Charge Code: } 118108 \\ \text { B\&R Code: } & \text { Total Pages: } 47\end{array}$

Key Words: Strontium, Strontium-90, Total Organic Carbon, TOC, HTWOS Sr, Sr-90, Solubility, Partitioning, wash Eactor, Low-Activity Waste, LAW Feed

Abstract: A new correlation was developed to estimate the concentration of strontium-90 in a waste solution based on total organic carbon. This correlation replaces the strontium-90 wash factors, and when applied in the Hanford Tank waste Operations Simulator, significantly reduced the estimated quantity of strontium-90 in the delivered low-activity waste feed. This is thought to be a more realistic estimate of strontium-90 than using the wash-factor method.

TRADEMARK DISCLAIMER. Reference herein to any specific commercial product, process, or service by trade name, trademark, manufacturer, or otherwise, does not necessarily constitute or imply its endorsement, recommendation, or favoring by the United States Government or any agency thereof or its contractors or subcontractors.

Printed in the United States of America. To obtain copies of this document, contact: Document Control Services, P.O. Box 950, Mailstop H6-08, Richland WA 99352, Phone (509) 372-2420; Fax (509) 376-4989.
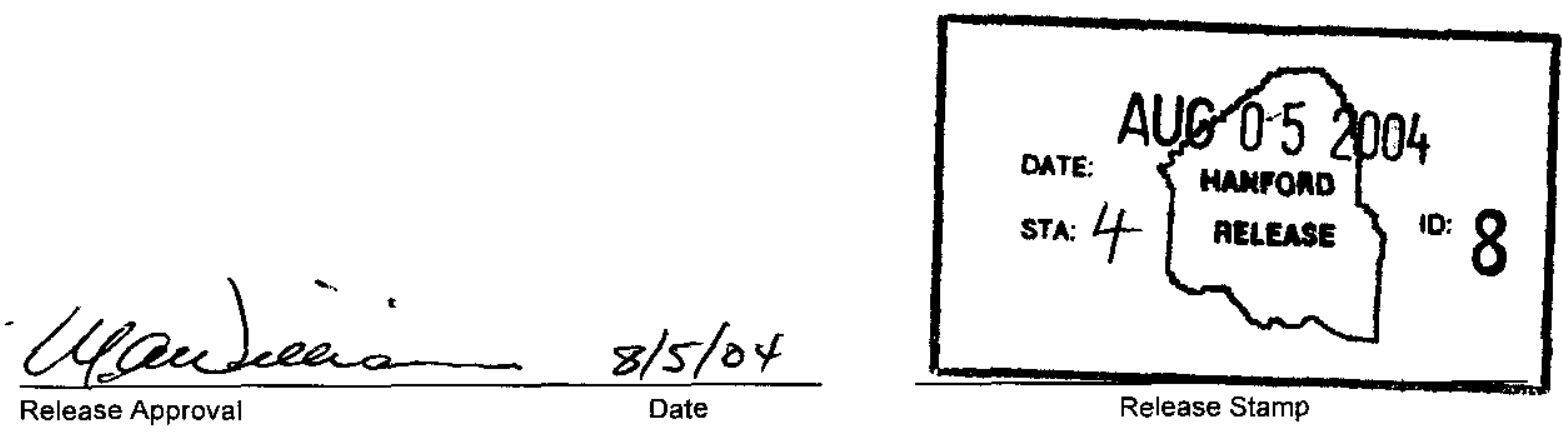

Approved For Public Release 
RPP-21807

Revision 0

\title{
STRONTIUM-90 LIQUID CONCENTRATION SOLUBILITY CORRELATION IN THE HANFORD TANK WASTE OPERATIONS SIMULATOR
}

\author{
T. M. Hohl \\ D. E. Place \\ R. S. Wittman \\ CH2M HILL Hanford Group, Inc.
}

Date Published

August 2004

\section{CH2MHILL \\ Hanford Group, Inc.}

Prepared for the U.S. Department of Energy

Office of River Protection

Contract \#DE-AC27-99RL14047, Modification M030

Approved for Public Release; Further Dissemination Unlimited 
RPP-21807 Rev. 0

This page intentionally left blank. 


\section{CONTENTS}

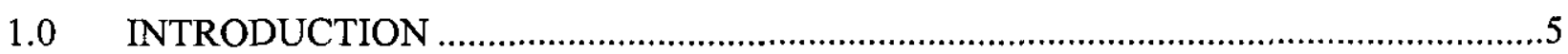

2.0 DERIVATION OF THE STRONTIUM-90 SOLUBILITY CORRELATION...................5

$2.1 \quad$ Criteria for Solubility Estimates ......................................................................6

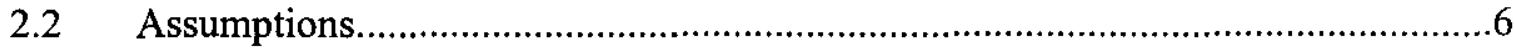

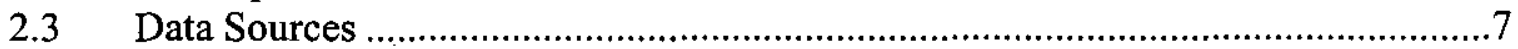

2.4 Development of the Strontium-90 Solubility Correlation .......................................

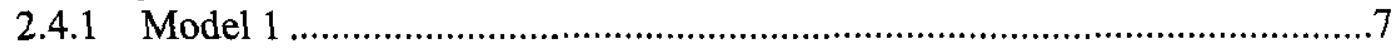

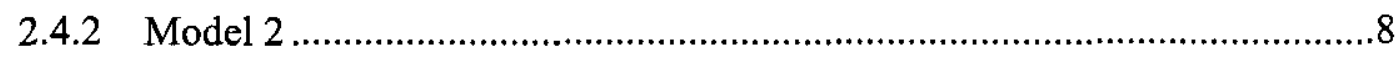

2.5 Recommended Correlation for Strontium-90 Solubility........................................8

3.0 IMPLEMENTATION IN THE HANFORD TANK WASTE

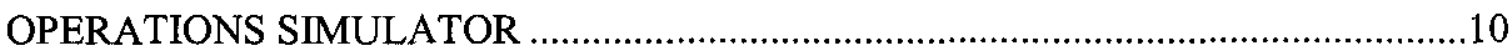

3.1 Incorporation of Strontium Solubility Model into the Hanford Tank Waste

Operations Simulator .....................................................................................10

3.2 Effect of Strontium Correlation on Results ………..............................................13

3.2.1 Strontium-90 to Sodium Ratio Distribution...............................................13

3.2.2 Overall Strontium Mass Balance ………................................................13

3.2.3 Impact to High-Level Waste and Low-Activity Waste Glass ....................14

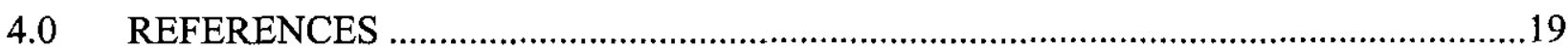

\section{LIST OF FIGURES}

Figure 2-1. Strontium Concentration to Total Organic Carbon Concentration Correlations. ....... 9

Figure 3-1. Strontium-90 to Sodium Distributions Using Strontium Wash

Factors and Correlation. 15

Figure 3-2. High-Level Glass Production Using Strontium Wash Factors and Correlation. ...... 16

Figure 3-3. Low-Activity Glass Production Using Strontium Wash Factors and Correlation. ... 17

\section{LIST OF TABLES}

Table 3-1. Independent Check of Hanford Tank Waste Operations Simulator

Calculated Strontium- 90 concentrations. 12

\section{APPENDIX}

Appendix A A-1 


\section{LIST OF TERMS}

$\begin{array}{ll}\text { BBI } & \text { Best-Basis Inventory } \\ \text { DST } & \text { Double-shell tank } \\ \text { g/L } & \text { gram per Liter } \\ \text { HDW } & \text { Hanford Defined Waste } \\ \text { HLW } & \text { High-level waste } \\ \text { HTWOS } & \text { Hanford Tank Waste Operations Simulator } \\ \text { LAW } & \text { Low activity waste } \\ \text { Sr-90 } & \text { Strontium-90 } \\ \text { SST } & \text { Single-shell tank } \\ \text { TCD } & \text { Tank Characterization Database } \\ \text { TFCOUP } & \text { Tank Farm Contractor Operation and Utilization Plan } \\ \text { TIA } & \text { Technical integration activity } \\ \text { TOC } & \text { Total organic carbon } \\ \mu \text { Ci/mL } & \text { micro-Curies per milli-Liter } \\ \mu \text { g/mL } & \text { micro-gram per milli-Liter } \\ \text { WTP } & \text { Waste Treatment and Immobilization Plant }\end{array}$




\subsection{INTRODUCTION}

This report presents a correlation for the concentration of strontium-90 (Sr-90) in the liquid phase as a function of total organic carbon (TOC) concentration for Hanford Site single-shell tank (SST) and double-shell tank (DST) wastes. This work was performed as a follow-up action to one of the recommendations made during an assessment of out-of-specification feed sanctioned by the Technical Integration Activity (TIA) Team. The TIA Team is comprised of members from the U.S. Department of Energy, Office of River Protection, Bechtel National, Inc., and CH2M HILL Hanford Group, Inc. The assessment found that the wash factor data for Sr-90 was "poor". The assessment also concluded that the Hanford Defined Waste (HDW) model (LA-UR-96-3860, Hanford Tank Chemical and Radionuclide Inventories: HDW Model Rev. 4) solubility creates unrealistically high Sr-90 liquid concentrations. The Sr-90 correlation was developed to take the place of water wash factors for Sr-90 since the use of water wash factors for strontium was incorrectly predicting that $>20 \%$ of the feed delivered to the Waste Treatment and Immobilization Plant (WTP) would require strontium removal (D-03-DESIGN-005 2003, Evaluation of Tank Waste Wash and Leach Factors).

The correlation is based on 51 pairs of liquid-phase Sr-90 and TOC data. Two models were developed based on this, data. The first model correlation (Model 1) fit well but had some unacceptable drawbacks. The second model correlation (Model 2) was also a good fit and did not have the same drawbacks as the Model 1 correlation. Therefore, the Model 2 correlation was chosen to be the preferred equation. More details of the derivation of the Sr-90 to TOC correlation is documented in Section 2.0.

Sr-90 concentrations in low-activity waste (LAW) and high-level waste (HLW) feed liquids are tracked using the Hanford Tank Waste Operations Simulator (HTWOS) to see if they meet WTP contract limits. The description of how the correlation is integrated into the HTWOS model and demonstration of its successful incorporation is presented in Section 3.0.

\subsection{DERIVATION OF THE STRONTIUM-90 SOLUBILITY CORRELATION}

Correlations between the Sr-90 concentrations in solution and the liquid phase TOC concentrations were established using sample-based data from the Best-Basis Calculation Detail Reports (TWINS 2004a). The Best-Basis Inventory (BBI) data are traceable to sample data reported in the Tank Characterization Database (TCD) (TWINS 2004b). 


\subsection{CRITERIA FOR SOLUBILITY ESTIMATES}

The criteria for the Sr-90 solubility correlation evolved during development. The following points summarize the results of several discussions:

- The correlation must be simple and easy to implement in HTWOS. Iterative or logical branching calculations are to be avoided whenever possible. A single equation describing a continuous curve is preferred.

- Estimates are to be best estimate (Best-Basis) as opposed to conservative, bounding limits.

- Dependencies must rely on analytes that are already included in the standard BBI analyte list (24 chemicals and 46 radionuclides).

- Equations should be tied to solubility theory or postulated behavior in as far as is practical.

- Equations must not result in abnormal behavior, such as negative concentrations or regions where the solubility moves opposite to the expected direction (e.g. reductions in metal/radionuclide solubility with increasing TOC).

- Existing data sources to be used whenever possible.

\section{$2.2 \quad$ ASSUMPTIONS}

A number of assumptions are necessary to establish a correlation for Sr-90 solubility with TOC.

1. Strontium solubility behavior during retrieval and feed staging will be similar to that currently exhibited in the stored tanks wastes.

2. The concentrations of organic complexants and the solution $\mathrm{pH}$ are the primary factors influencing strontium solubility.

3. Wastes will be retrieved to DSTs prior to feed delivery to the WTP. Since corrosion specifications for the DSTs require a minimum of 0.01 molar free hydroxide, $\mathrm{pH}$ will not significantly influence strontium solubility after waste retrieval.

4. The TOC concentration is assumed to be a suitable surrogate for the unknown organic species which are forming the actual soluble complex with strontium.

5. The Sr-90 liquid concentration is assumed to be an acceptable substitute for the total chemical strontium concentration (which is actually the controlling factor for solubility). This assumption is required as chemical strontium is not accurately measured in the Hanford tank waste liquids. Approximately $99 \%$ of the strontium Inductively Coupled Plasma "ICP" analyses for liquids available in the TCD (TWINS 2004b) are below detection limits, "R" qualified (data not usable) or "J" qualified (estimates). The remaining data are likely to contain a large percentage of outliers due to the proximity to the analytical detection limits.

6. Chemical strontium will partition identically to $\mathrm{Sr}-90$ when subjected to water washing. The fraction of the chemical strontium transferred between phases during dissolution or precipitation will match that of Sr-90 (i.e. no isotopic depletion or enrichment for material transferred between phases). 
7. Decay of Sr-90 from the January 1, $2001 \mathrm{BBI}$ radionuclide baseline date will be ignored as accurate measurements of chemical strontium are unavailable. Consequently the strontium isotopic distribution can not be established.

\subsection{DATA SOURCES}

The Sr-90 and TOC concentrations summarized by the Best-Basis Calculation Report (TWINS 2004a) were selected as the data source for developing the Sr-90 solubility correlation since an adequate number of sample-based data points is ready available without extensive data manipulation and evaluation. The initial query of TOC and Sr-90 data was made in December 2003, and updated in March 2004. Fifty-three data pairs were available for liquid phases, most representing low Sr-90 and TOC concentrations. Two data sources were excluded from the data evaluation: tank 241-C-103 and tank 241-U-106.

The tank 241-C-103 data represented a solution that was below $\mathrm{pH} 10$. Sr-90 solubility is known to increase with reduced $\mathrm{pH}$. The effects of TOC (if any) would be masked by the $\mathrm{pH}$ effects.

The TOC in the 241-U-106 liquid phase appears to be totally different than for any other high TOC waste (the Sr-90 concentration would be expected to be much higher than that measured). The raw data supporting the BBI concentrations were examined and appear to be valid. There is a significant difference between the mean TOC concentrations measured by persulfate oxidation and furnace oxidation analytical methods $(3.38 \mathrm{E}+04 \mu \mathrm{g} / \mathrm{mL}$ versus $4.28 \mathrm{E}+04 \mu \mathrm{g} / \mathrm{mL}$ respectively). This difference suggests that the TOC in the tank 241-U-106 liquid phase is resistant to oxidation since furnace oxidation generally results in more complete oxidization than persulfate oxidation method when a "rugged" organic is present. The tank 241-U-106 data were excluded from curve fitting as no reasonable relationship between Sr-90 and TOC concentrations can accommodate this divergent result.

\subsection{DEVELOPMENT OF THE STRONTIUM-90 SOLUBILITY CORRELATION}

\subsubsection{Model 1}

The first model developed was of the form $y=A+(B-A) /\left(1+\exp \left(-\lambda^{*}(x-C)\right)\right)$ which assumes upper and lower asymptotes (constants $\mathrm{B}$ and $\mathrm{A}$ respectively). The lower asymptote was set at the average of all Sr-90 concentrations corresponding to less than $10 \mathrm{~g} / \mathrm{L} \mathrm{TOC}$, and the upper asymptote was set slightly above the highest $\mathrm{Sr}-90$ concentration reported. The anomalous tank 241-U-106 data was excluded from the curve fitting. The remaining two constants ( $\mathrm{C}$ and $\lambda$ ) were optimized using the Solver function in an Excel spreadsheet by minimizing the sum of the squared deviations between predicted and measured Sr-90 concentrations. Weighting factors of 10 were applied to squared deviations for TOC concentrations of greater than $10 \mathrm{~g} / \mathrm{L}$ to keep the numerous data points with low TOC and Sr-90 concentrations from controlling the curve fit at higher TOC concentrations. 
The resulting data fit was excellent (see Figure 2-1). However, the model has three drawbacks: 1) there was no assurance that an upper solubility limit actually exists, 2) there is no tie-in to solubility theory or postulated $\mathrm{Sr}-90$ behavior, and 3) the excellent fit is misleading since four constants were used to achieve this fit.

\subsubsection{Model 2}

With the exclusion of the data for tank 241-U-106, the data are fit reasonably well by a quadratic equation of the form $\mathrm{AX}^{2}+\mathrm{BX}+\mathrm{C}$ (correlation coefficient of $97 \%$ ); however, the result dips below zero Sr-90 concentration and includes a region of negative slope with increasing TOC. The second order dependence on the TOC concentration suggests that two molecules of the unknown organic chelating agent are required to complex each mole of strontium (which has a +2 valence). Additionally, the Sr-90 solubility was thought to consist of two components: a low baseline solubility representing sparingly soluble metal compounds and the additive effects of chelation at higher TOC concentrations.

Therefore, a truncated equation of the form $\mathrm{AX}^{2}+\mathrm{B}$ was adopted, for which the variable $\mathrm{B}$ was set at the average $\mathrm{Sr}-90$ concentration for all data points having less than $10 \mathrm{~g} / \mathrm{L} \mathrm{TOC}$.

Weighting factors of 10 were again applied to squared deviations for TOC concentrations of greater than 10 to improve the fit at higher TOC concentrations. The resulting correlation is not quite as good as with Model 1, but it is still excellent (correlation coefficient of 97\%). The Model 2 correlation did not assume an upper-bounding Sr-90 solubility limit for highly complexed waste and the correlation exhibits a postulated solubility behavior for $\mathrm{Sr}-90$ (see Figure 2-1).

\subsection{RECOMMENDED CORRELATION FOR STRONTIUM-90 SOLUBILITY}

Model $2\left[{ }^{90} \mathrm{Sr}\right.$ Concentration $=8.5897 \mathrm{E}-08 \times(\mathrm{TOC})^{2}+0.5628$ in units of $\mu \mathrm{Ci} / \mathrm{mL}$ and $\left.\mu \mathrm{g} / \mathrm{mL}\right]$ is the preferred equation describing Sr-90 solubility as a function of TOC as it is simpler, has fewer constants and better fits postulated behavior. 
Figure 2-1. Strontium Concentration to Total Organic Carbon Concentration Correlations.

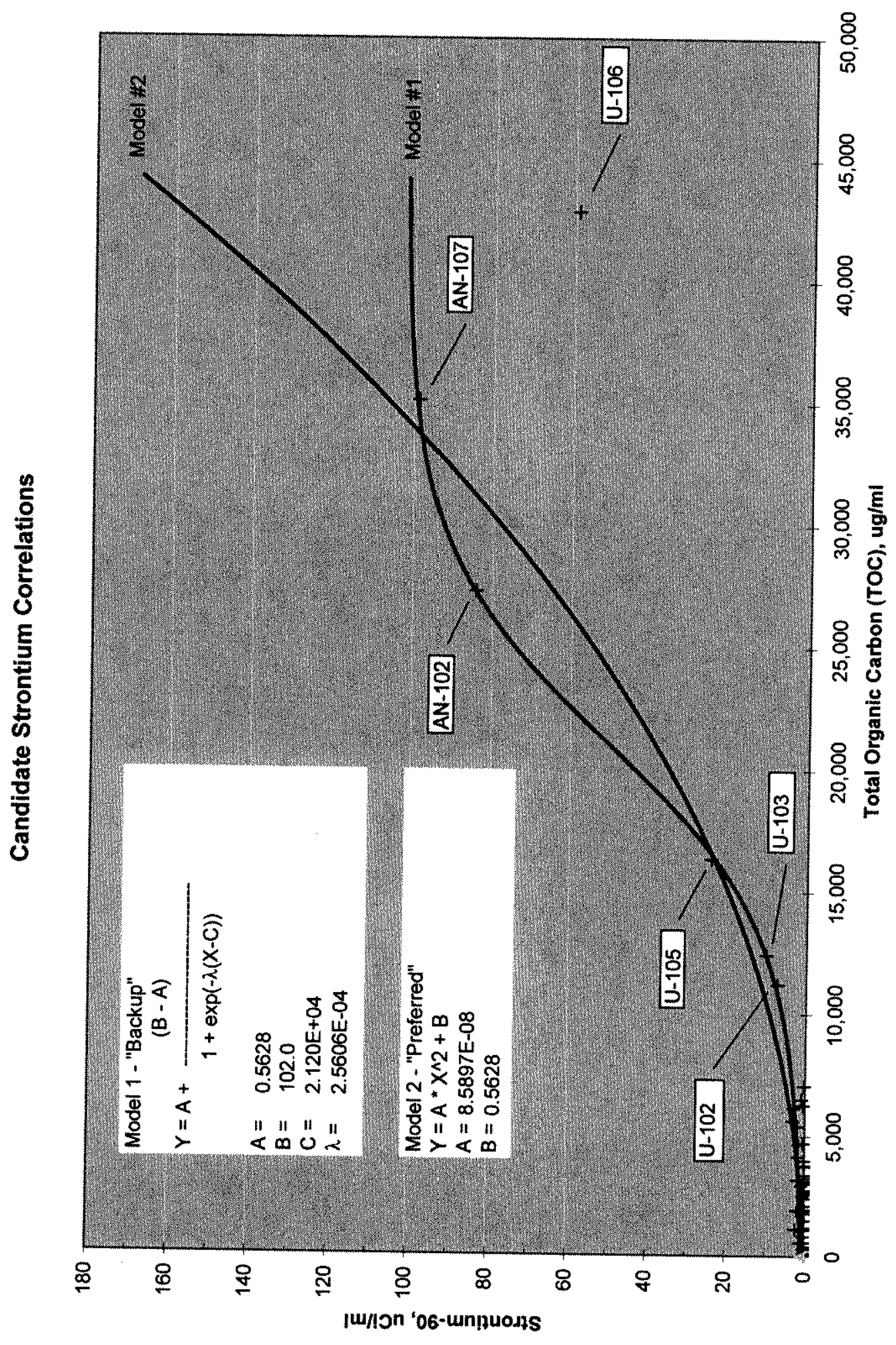




\subsection{IMPLEMENTATION IN THE HANFORD TANK WASTE OPERATIONS SIMULATOR}

\subsection{INCORPORATION OF STRONTIUM SOLUBILITY MODEL INTO THE HANFORD TANK WASTE OPERATIONS SIMULATOR}

A test case was run in HTWOS to test the implementation of a strontium solubility model using the preferred correlation developed in Section 2. The detailed assumptions used in this model are contained in Appendix A. For this test case it is assumed that the partitioning of all strontium between solid and liquid is determined by Model 2, which is described in the previous section. The partitioning for all components other than strontium is calculated once in the HTWOS model by applying water wash factors (HNF-3157, Rev. 0A, Best-Basis Wash and Leach Factor Analysis). Given the TOC partitioning determined from the wash factors, the concentration limit for the Sr-90 is set from the relationship

$$
C_{\mathrm{Sr}-90}=A C_{\mathrm{TOC}}^{2}+B
$$

where $A=8.5897 \times 10^{-8}(\mu \mathrm{Ci} / \mathrm{mL}) /(\mu \mathrm{g} / \mathrm{mL})^{2}, B=0.5628 \mu \mathrm{Ci} / \mathrm{mL}$ and $C_{\text {TOC }}$ is the TOC concentration. To satisfy Equation (1) in HTWOS, the strontium concentration is recalculated for any mixing operation. For the receiver tank, the calculation is performed after every transfer time step. The concentrations in the sending tank are normally unchanged during a transfer. Since the relationship [Equation (3-1)] is specified for the Sr-90 concentration alone, an assumption for handling the remainder of the chemical strontium (non Sr-90) is necessary. To avoid isotopic selectivity for the strontium partitioning it was assumed that the $\mathrm{Sr}-90 /$ strontium ratio of the phase losing material is preserved. Therefore, the precipitating strontium adds to the existing solids in the same $\mathrm{Sr}-90 / \mathrm{Sr}$-total ratio $r$ that it has in the liquid; likewise, the dissolving strontium solids adds to the liquid in the same ratio as in the solids. It should be noted that the simple form of Equation (3-1) can be treated explicitly in HTWOS. This is true only because the density calculation is linear. Indirectly the mass of strontium affects the total volume and therefore the concentration of TOC. In this case the allowed mass change of Sr-total $\left(\Delta M_{\mathrm{Sr}}\right)$ at the limit of Equation (3-1) is the solution of the quadratic equation

$$
\begin{gathered}
{\left[r \frac{\partial V_{L}}{\partial M_{\mathrm{Sr}}}-B\left(\frac{\partial V_{L}}{\partial M_{\mathrm{Sr}}}\right)^{2}\right] \Delta M_{\mathrm{Sr}}^{2}+\left(r V_{L}+\frac{\partial V_{L}}{\partial M_{\mathrm{Sr}}} M_{\mathrm{Sr}-90}-2 B V_{L} \frac{\partial V_{L}}{\partial M_{\mathrm{Sr}}}\right) \Delta M_{\mathrm{Sr}}} \\
+M_{\mathrm{Sr}-90} V_{L}-A M_{\mathrm{TOC}}^{2}-B V_{L}^{2}=0
\end{gathered}
$$

where:

$\begin{array}{lll}r & = & \text { "losing" phase Sr-90/Sr-total mass ratio } \\ V_{L} & = & \text { initial total liquid volume } \\ M_{S r} & = & \text { initial Sr-total mass } \\ B & = & 0.5628 \mu \mathrm{Ci} / \mathrm{mL} \\ M_{S r-90} & = & \text { initial } \mathrm{Sr}-90 \text { mass } \\ A & = & 8.5897 \times 10^{-8}(\mu \mathrm{Ci} / \mathrm{mL}) /(\mu \mathrm{g} / \mathrm{mL})^{2} \\ M_{T O C} & = & \text { initial TOC mass }\end{array}$


For more complicated solubility models a closed expression such as Equation (3-2) will not be practical. To allow for more general models in future runs, it was shown that an implicit calculation using a fixed point iteration method rapidly converges to the same result typically after five iterations.

As a test of the HTWOS application of Equation (3-1), a hand calculation for the Sr-90 concentration for each HLW and LAW feed batch was performed and compared with the HTWOS result. Table 3-1 shows selected results from the test using HTWOS reported values good to four significant figures. In each batch the Sr-90 concentration was equal to the Equation (3-1) limit within the expected precision. 
Table 3-1. Independent Check of Hanford Tank Waste Operations Simulator Calculated Strontium-90 Concentrations.

\begin{tabular}{|c|c|c|c|c|c|c|c|c|c|}
\hline \multirow[t]{2}{*}{ Batch } & \multirow[t]{2}{*}{ Type } & $\begin{array}{c}\text { TOC } \\
\text { Aqueous }^{2}\end{array}$ & $\begin{array}{c}\text { Liquid } \\
\text { Volume }^{\mathrm{b}}\end{array}$ & $\begin{array}{c}\text { Sr-90 } \\
\text { Aqueous }^{\mathrm{c}}\end{array}$ & $\begin{array}{l}\text { Sr-90 } \\
\text { Solid }^{d}\end{array}$ & TOC $^{e}$ & $\begin{array}{c}\text { HTWOS } \\
\text { Sr-90 }^{\mathrm{f}}\end{array}$ & $\begin{array}{c}\text { Calculated } \\
\text { Sr-90 }^{\mathrm{g}}\end{array}$ & \multirow[t]{2}{*}{ Difference $^{h}$} \\
\hline & & (kg-mol) & (gal) & (kg-mol) & (kg-mol) & $(\mu \mathrm{g} / \mathrm{ml})$ & $(\mu \mathrm{Ci} / \mathrm{ml})$ & $(\mu \mathrm{Ci} / \mathrm{ml})$ & \\
\hline 1 & LAW & $5.49 \mathrm{E}+02$ & $7.12 \mathrm{E}+05$ & $2.40 \mathrm{E}-04$ & $5.80 \mathrm{E}-02$ & 2448.2 & 1.0776 & 1.0776 & $6.72 \mathrm{E}-09$ \\
\hline 3 & HLW & $4.45 \mathrm{E}+01$ & $1.51 \mathrm{E}+05$ & $3.02 \mathrm{E}-05$ & $6.63 \mathrm{E}-02$ & 934.6 & 0.6378 & 0.6378 & $2.58 \mathrm{E}-09$ \\
\hline 4 & HLW & $4.45 \mathrm{E}+01$ & $1.51 \mathrm{E}+05$ & $3.02 \mathrm{E}-05$ & $6.63 \mathrm{E}-02$ & 934.6 & 0.6378 & 0.6378 & $-1.85 \mathrm{E}-08$ \\
\hline 7 & LAW & $9.72 \mathrm{E}+02$ & $1.21 \mathrm{E}+06$ & $4.25 \mathrm{E}-04$ & $1.15 \mathrm{E}-04$ & 2554.5 & 1.1233 & 1.1233 & $-3.15 \mathrm{E}-09$ \\
\hline 8 & HLW & $2.34 \mathrm{E}+01$ & $1.55 \mathrm{E}+05$ & $2.83 \mathrm{E}-05$ & $5.76 \mathrm{E}-02$ & 478.2 & 0.5824 & 0.5824 & $-1.51 \mathrm{E}-08$ \\
\hline 9 & HLW & $2.34 \mathrm{E}+01$ & $1.55 \mathrm{E}+05$ & $2.83 \mathrm{E}-05$ & $5.76 \mathrm{E}-02$ & 478.2 & 0.5824 & 0.5824 & $-1.51 \mathrm{E}-08$ \\
\hline 11 & HLW & $2.34 \mathrm{E}+01$ & $1.55 \mathrm{E}+05$ & $2.83 \mathrm{E}-05$ & $5.76 \mathrm{E}-02$ & 478.2 & 0.5824 & 0.5824 & $-1.51 \mathrm{E}-08$ \\
\hline 12 & HLW & $2.30 \mathrm{E}+01$ & $1.53 \mathrm{E}+05$ & $2.78 \mathrm{E}-05$ & $5.66 \mathrm{E}-02$ & 478.2 & 0.5824 & 0.5824 & $1.73 \mathrm{E}-09$ \\
\hline 13 & HLW & $1.68 \mathrm{E}+02$ & $1.57 \mathrm{E}+05$ & $7.64 \mathrm{E}-05$ & $2.67 \mathrm{E}-02$ & 3401.6 & 1.5567 & 1.5567 & $1.52 \mathrm{E}-08$ \\
\hline 15 & HLW & $1.68 \mathrm{E}+02$ & $1.57 \mathrm{E}+05$ & 7.64E-05 & $2.63 \mathrm{E}-02$ & 3401.7 & 1.5568 & 1.5568 & $5.28 \mathrm{E}-08$ \\
\hline 19 & HLW & $1.33 \mathrm{E}+02$ & $1.24 \mathrm{E}+05$ & $6.06 \mathrm{E}-05$ & $2.10 \mathrm{E}-02$ & 3401.3 & 1.5565 & 1.5565 & $4.74 \mathrm{E}-08$ \\
\hline 28 & HLW & $1.01 \mathrm{E}+02$ & $1.48 \mathrm{E}+05$ & $4.46 \mathrm{E}-05$ & $1.96 \mathrm{E}-02$ & 2163.1 & 0.9647 & 0.9647 & $-2.47 \mathrm{E}-08$ \\
\hline 29 & HLW & $1.51 \mathrm{E}+01$ & $2.23 E+04$ & $6.70 \mathrm{E}-06$ & $2.99 \mathrm{E}-03$ & 2156.6 & 0.9623 & 0.9623 & $-3.58 \mathrm{E}-09$ \\
\hline 30 & HLW & $4.89 \mathrm{E}+01$ & $1.43 \mathrm{E}+05$ & $2.98 \mathrm{E}-05$ & $2.08 \mathrm{E}-02$ & 1081.9 & 0.6633 & 0.6633 & $9.61 \mathrm{E}-09$ \\
\hline 31 & LAW & $4.32 \mathrm{E}+02$ & $6.82 E+05$ & $1.94 \mathrm{E}-04$ & $9.58 \mathrm{E}-04$ & 2011.6 & 0.9104 & 0.9104 & $9.28 \mathrm{E}-09$ \\
\hline 32 & HLW & $4.89 \mathrm{E}+01$ & $1.43 E+05$ & $2.98 \mathrm{E}-05$ & $2.07 \mathrm{E}-02$ & 1081.9 & 0.6633 & 0.6633 & $-3.79 \mathrm{E}-09$ \\
\hline 33 & HLW & $4.89 \mathrm{E}+01$ & $1.43 E+05$ & $2.98 \mathrm{E}-05$ & $2.07 \mathrm{E}-02$ & 1081.9 & 0.6633 & 0.6633 & $1.26 \mathrm{E}-08$ \\
\hline 35 & LAW & $4.81 \mathrm{E}+02$ & $7.65 \mathrm{E}+05$ & $2.17 \mathrm{E}-04$ & $1.61 \mathrm{E}-03$ & 1995.6 & 0.9049 & 0.9049 & $1.63 \mathrm{E}-08$ \\
\hline 229 & HLW & $4.97 \mathrm{E}+01$ & $1.55 \mathrm{E}+05$ & $3.17 \mathrm{E}-05$ & $4.44 \mathrm{E}-03$ & 1015.6 & 0.6514 & 0.6514 & $5.68 \mathrm{E}-09$ \\
\hline 230 & HLW & $3.42 \mathrm{E}+01$ & $1.56 \mathrm{E}+05$ & $2.95 \mathrm{E}-05$ & $5.82 \mathrm{E}-03$ & 697.7 & 0.6046 & 0.6046 & $-3.27 \mathrm{E}-09$ \\
\hline 231 & HLW & $3.42 \mathrm{E}+01$ & $1.56 \mathrm{E}+05$ & $2.95 \mathrm{E}-05$ & $5.81 \mathrm{E}-03$ & 697.2 & 0.6046 & 0.6046 & $-1.34 \mathrm{E}-08$ \\
\hline 232 & HLW & $3.42 \mathrm{E}+01$ & $1.56 \mathrm{E}+05$ & $2.95 \mathrm{E}-05$ & $5.81 \mathrm{E}-03$ & 696.7 & 0.6045 & 0.6045 & $2.06 \mathrm{E}-08$ \\
\hline 233 & HLW & $3.42 \mathrm{E}+01$ & $1.56 \mathrm{E}+05$ & $2.95 \mathrm{E}-05$ & $5.80 \mathrm{E}-03$ & 696.0 & 0.6044 & 0.6044 & $-2.14 \mathrm{E}-09$ \\
\hline 234 & HLW & $3.41 \mathrm{E}+01$ & $1.56 \mathrm{E}+05$ & $2.95 \mathrm{E}-05$ & $5.79 \mathrm{E}-03$ & 695.0 & 0.6043 & 0.6043 & $-7.91 \mathrm{E}-09$ \\
\hline 235 & HLW & $3.40 \mathrm{E}+01$ & $1.56 \mathrm{E}+05$ & $2.95 \mathrm{E}-05$ & $5.78 \mathrm{E}-03$ & 693.2 & 0.6041 & 0.6041 & $2.17 \mathrm{E}-08$ \\
\hline 236 & HLW & $2.10 \mathrm{E}+01$ & $1.50 \mathrm{E}+05$ & $2.72 \mathrm{E}-05$ & $4.57 \mathrm{E}-03$ & 445.5 & 0.5798 & 0.5798 & $2.79 \mathrm{E}-08$ \\
\hline 237 & HLW & $2.10 \mathrm{E}+01$ & $1.50 \mathrm{E}+05$ & $2.72 \mathrm{E}-05$ & $4.57 \mathrm{E}-03$ & 445.2 & 0.5798 & 0.5798 & $1.90 \mathrm{E}-09$ \\
\hline 238 & HLW & $2.10 \mathrm{E}+01$ & $1.50 \mathrm{E}+05$ & $2.72 \mathrm{E}-05$ & $4.57 \mathrm{E}-03$ & 444.8 & 0.5798 & 0.5798 & $-1.55 \mathrm{E}-08$ \\
\hline 239 & HLW & $2.10 \mathrm{E}+01$ & $1.50 \mathrm{E}+05$ & $2.72 \mathrm{E}-05$ & $4.56 \mathrm{E}-03$ & 444.4 & 0.5798 & 0.5798 & $1.25 \mathrm{E}-08$ \\
\hline 240 & HLW & $2.10 \mathrm{E}+01$ & $1.50 \mathrm{E}+05$ & 2.72E-05 & $4.56 \mathrm{E}-03$ & 443.7 & 0.5797 & 0.5797 & $1.16 \mathrm{E}-08$ \\
\hline
\end{tabular}

Notes:

LAW $=$ Low-activity waste

HLW $=$ High-level waste

HTWOS $=$ Hanford Tank Waste Operations Simulator

Sr-90 $=$ Strontium-90

TOC $=$ Total Organic Carbon

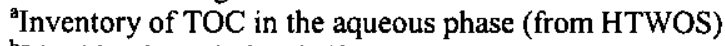

${ }^{\mathrm{b}} \mathrm{Liquid}$ volume in batch (from HTWOS)

${ }^{\varepsilon}$ Inventory of $\mathrm{Sr}-90$ in the aqueous phase (from HTWOS)

${ }^{\mathrm{d}}$ Inventory of $\mathrm{Sr}-90$ in the solid phase (from HTWOS)

${ }^{e}$ Concentration of TOC in the aqueous phase (from HTWOS)

${ }^{f}$ Concentration of Sr-90 in the aqueous phase (calculated from within HTWOS using TOC correlation)

${ }^{8}$ Concentration of Sr-90 in the aqueous phase (calculated externally by hand using TOC correlation)

${ }^{\text {h}}$ Difference between internal HTWOS calculation and external hand calculation (small difference indicates agreement) 
RPP-21807 Rev. 0

\subsection{EFFECT OF STRONTIUM CORRELATION ON RESULTS}

As stated before, the Sr-90 correlation was developed to take the place of water wash factors for Sr-90 since the use of water wash factors for strontium was incorrectly predicting that a significant portion of the feed delivered to the WTP would require strontium removal. In incorporating this correlation into HTWOS some impacts are expected to model results that are dependent on strontium solubility while other factors are expected to remain unchanged when compared with a model scenario based on wash factors for Sr-90 solubility.

\subsubsection{Strontium-90 to Sodium Ratio Distribution}

A comparison was made of the distribution of $\mathrm{Sr}-90$ to sodium prior to and after application of the Sr-90 correlation. The initial condition is based on the scenario documented in HNF-SDWM-SP-012, Rev. 5A, Tank Farm Contractor Operation and Utilization Plan" (TFCOUP) and is identified as TFCOUP Rev 5. The initial scenario utilized the strontium wash factors and the comparison scenario used the Sr-90 correlation instead of the strontium wash factors. This comparison is shown in Figure 3-1 and is on a percent of delivered sodium basis.

The figure shows that prior to application of the Sr-90 correlation (TFCOUP Rev. 5A), $69 \%$ of the modeled feed met Envelopes $\mathrm{A}$ and $\mathrm{B}$ with the remaining 31\% requiring additional pretreatment to remove strontium. Additionally, $3 \%$ of the feed would be out of specification for Sr-90 per WTP Contract, DE-AC27-01RV14136.

When the Sr-90 correlation is applied, $96 \%$ of the modeled feed met Envelopes A and B. Therefore only $4 \%$ of the liquid feed would require additional pretreatment to remove strontium. Additionally, none of the liquid feed would be out of specification for Sr-90 per the WTP contract (DE-AC27-01RV14136).

\subsubsection{Overall Strontium Mass Balance}

The overall $\mathrm{Sr}-90$ and elemental strontium is tracked during an HTWOS model run. Regardless of which method is used to calculate the quantity of strontium in solution, the total overall mass balance of strontium should not differ. To show that the overall strontium mass balance is not affected by replacement of the wash factors with the $\mathrm{Sr}-90$ correlation, a complete model run was performed and the final Sr-90 and elemental strontium inventories were compiled. For this exercise, inventories are defined to include Sr-90 and elemental strontium in DSTs and SSTs, as well as, in vitrified and other immobilized waste forms. These inventories were compared with the TFCOUP Rev. 5 run using strontium wash factors and also with the initial starting inventory, accounting for radiological decay of Sr-90. The result was that all three inventories (initial, TFCOUP Rev 5 run-based, and Sr-90 correlation based) were equal; verifying that the overall strontium mass balance was maintained. 


\subsubsection{Impact to High-Level Waste and Low-Activity Waste Glass}

The effect of the Sr-90 correlation was also assessed on its impact to HLW and LAW glass production. For HLW glass, the TFCOUP Rev. 5 run produced 9,429 canisters and was completed by September 15, 2027. After applying the correlation, 9,584 canisters of HLW glass were produced and HLW glass production was completed by January 23, 2028. The additional 155 canisters and four months additional time required to complete HLW vitrification is acceptable for this comparison. The reason for its acceptability is that the single model run with the Sr-90 correlation has variations in the incidental blending of waste well within the expected run-to-run variability when compared to the TFCOUP Rev. 5 run. The TFCOUP Rev. 5 run was optimized over several iterations to minimize plant outages and glass volume. If time was spent optimizing the model scenario using the Sr-90 correlation in the same manner as the TFCOUP Rev. 5 run, the quantity of HLW glass could be similarly reduced and completion of the HLW vitrification mission would be accomplished at an earlier date. Figure 3-2 shows the HLW glass production relationship between the TFCOUP Rev. 5 run and the scenario with the Sr-90 correlation.

The LAW glass production comparison was slightly affected. For LAW glass, the TFCOUP Rev. 5 run produced 27,850 packages and was completed by September 20, 2027. After applying the correlation, 27,854 packages of LAW glass were produced and LAW glass production was completed by January 23,2028 . The number of packages is essentially unchanged from the TFCOUP Rev. 5 run and the additional four months to complete processing is directly related to the delay in HLW glass mentioned previously. Figure 3-3 shows the LAW glass production relationship between the TFCOUP Rev. 5 run and the scenario with the Sr-90 correlation. 
RPP-21807 Rev. 0

Figure 3-1. Strontium-90 to Sodium Distributions Using Strontium Wash Factors and Correlation.

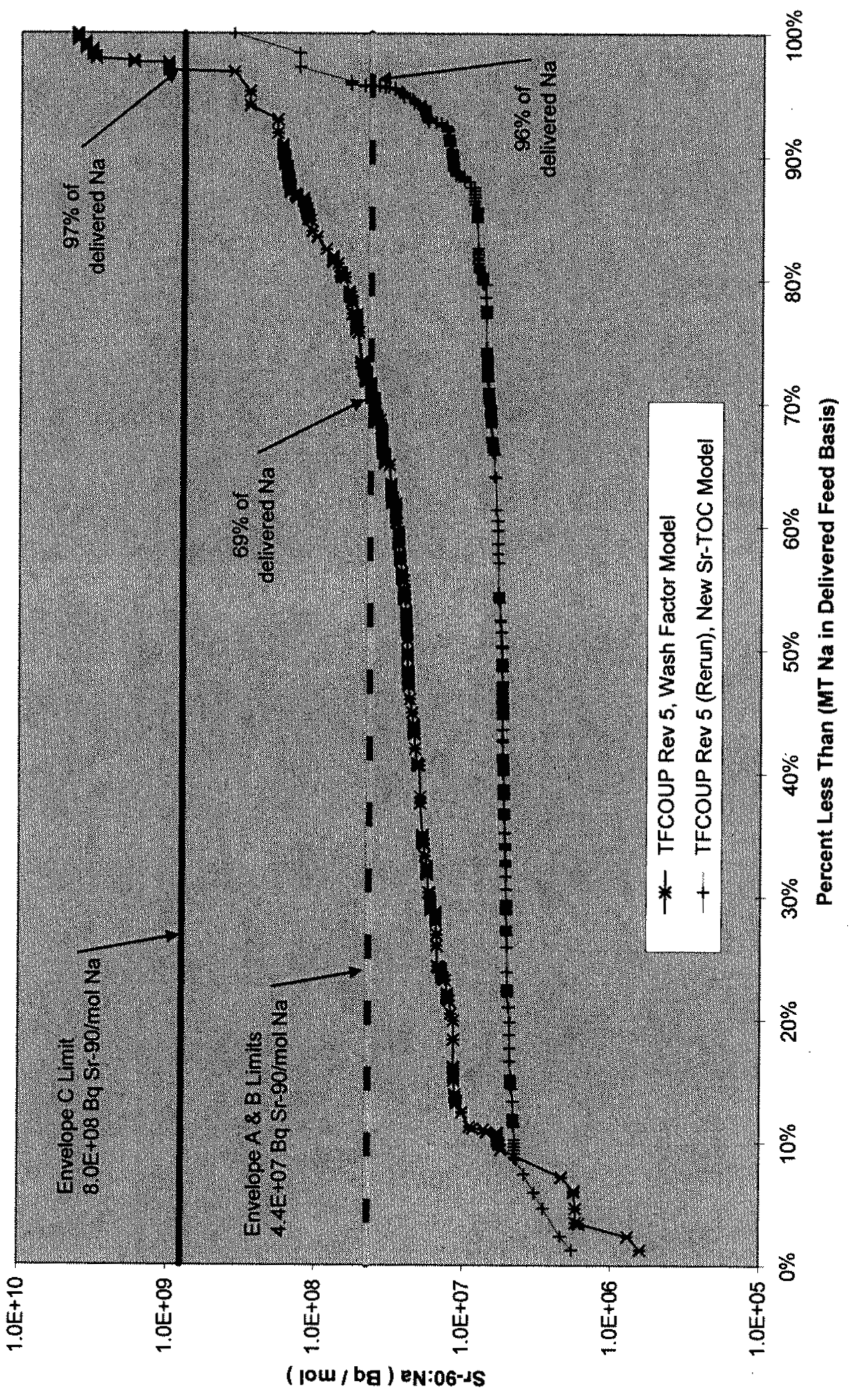




\section{RPP-21807 Rev. 0}

Figure 3-2. High-Level Glass Production Using Strontium Wash Factors and Correlation.

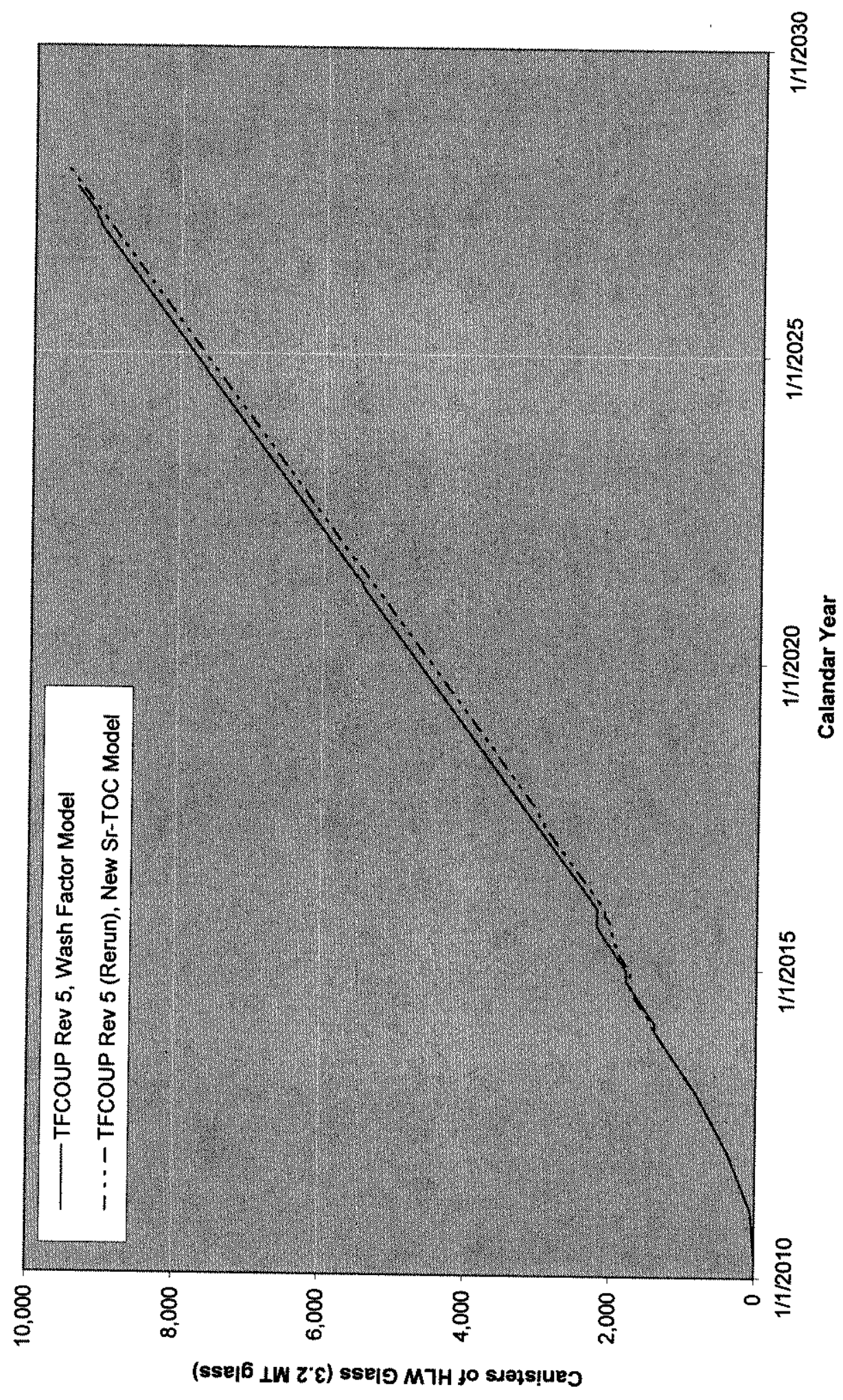


RPP-21807 Rev. 0

Figure 3-3. Low-Activity Glass Production Using Strontium Wash Factors and Correlation.

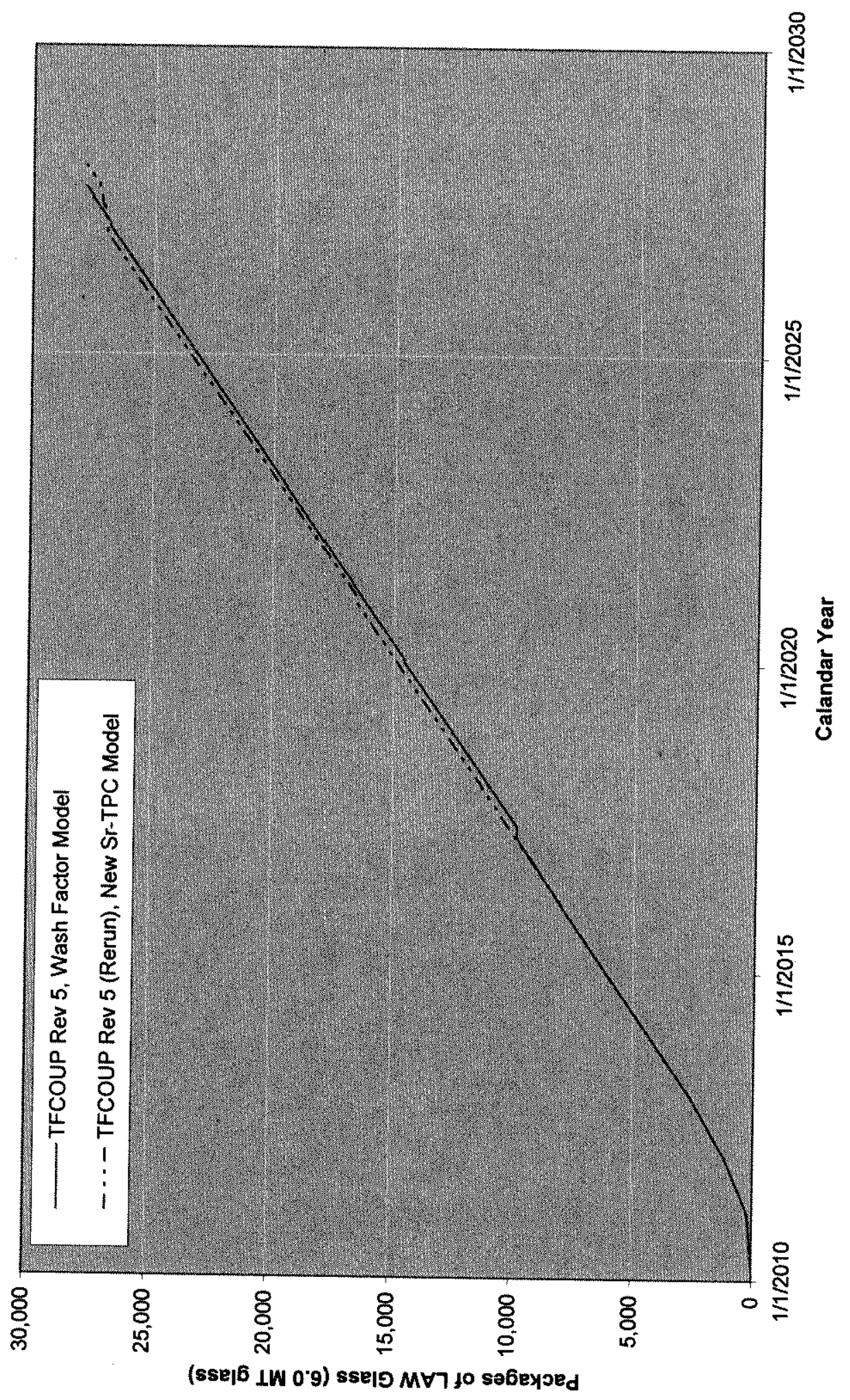


RPP-21807 Rev. 0

This page intentionally left blank. 
RPP-21807 Rev. 0

\subsection{REFERENCES}

D-03-DESIGN-005, 2003, Evaluation of Tank Waste Wash and Leach Factors, U.S. Department of Energy, Office of River Protection, Richland, Washington.

DE-AC27-01RV14136, 2000, WTP Contract, Modification A037, dated January 27, 2002, U.S. Department of Energy, Richland Operations Office, Richland, Washington.

LA-UR-96-3860, 1997, Hanford Tank Chemical and Radionuclide Inventories: HDW Model Rev. 4, Los Alamos National Laboratory, Los Alamos, New Mexico.

HNF-3157, Rev. 0A, 1999, Best-Basis Wash and Leach Factor Analysis, COGEMA Engineering, Richland, Washington.

HNF-SD-WM-SP-012, 2004, Tank Farm Contractor Operation and Utilization Plan, Rev. 5A, CH2M HILL Hanford Group, Inc., Richland, Washington.

TWINS, 2004a, Tank Waste Information Network System (TWINS), Queried 12/17/03 and 3/10/04, [Data Source Selection Forms, Best Basis Inventory, Best Basis Calculation Detail], http://twins.pnl.gov/twins.htm.

TWINS, 2004b, Tank Waste Information Network System (TWINS), [Data Source Selection Forms, Sample Analysis, Tank Results RPP 241, Tank Results (Hide QA records)], http://twins.pnl.gov/twins.htm 
RPP-21807 Rev. 0

This page intentionally left blank. 
RPP-21807 Rev. 0

\section{APPENDIX A}

\section{HANFORD TANK WASTE OPERATIONS SIMULATOR MODEL ASSUMPTIONS MATRIX}


RPP-21807 Rev. 0

This page intentionally left blank.

A-2 


\section{HTWOS Model Change Summary Form}

\begin{tabular}{l|l} 
Case Name & Sr Solubility Model Test
\end{tabular}

Objective: The purpose of this case is to test that a simple solubility model can be implemented in HTWOS to provide more realistic estimates of Sr in the WTP feed. This test is being performed as a follow-up action to one of the recommendations made during a joint ORP-BNI/WGI-CH2MHILL assessment of out-of-specification feed. The recommendation from the assessment was to develop and implement a simple Sr solubility model to take the place of water wash factors for Sr since the use of water wash factors for $\mathrm{Sr}$ was incorrectly predicting that $>20 \%$ of the feed delivered to the WTP would require Sr removal.

Scenario Change Summary - This section is focused on changes in key assumptions or key inputs to the model. The scenario described and documented in HNF-SD-WM-SP-012, Rev 5A, "Tank Farm Contractor Operation and Utilization Plan" will be maintained, except as needed to implement the Sr solubility model.

Software Change Summary - This section is focused on changes in the HTWOS model functionality and includes references to the Scenario Change Summary section where appropriate.

Incorporate and test the "Preferred" Sr solubility in HTWOS. If there are difficulties with the use of the "Preferred" model or anomalous results are seen, incorporate and test the "Backup" model, with the concurrence of the requestor. The two Sr models are shown on Figure A-2.

The solubility model should be applied to repartitioning the starting inventory and each time waste streams of two different compositions are mixed within the tank farm system. The Sr solubility model should not be used as part of the caustic leaching in the WTP or as part of any supplemental treatment.

Requestor or Point of Contact:

For reporting modeling status and resolving issues.

Paul Certa, 376-5429

\section{Supplemental Information:}

For all WTP feed deliveries (HLW and LAW), assess compliance with the Envelope A, B and C feed specifications by plotting Sr: $\mathrm{Na}$ ratio versus delivery date and versus feed batch. Prepare a Sr:Na distribution plot, on a sodium basis, and compare with similar plot created from TFCOUP Rev 5A data. See requestor for examples of these plots.

Confirm that overall $\mathrm{Sr}$ mass balance is maintained.

Identify and investigate any changes between this case and the TFCOUP Rev 5A with respect to LAW glass production curves, HLW glass production curves, treatment end date and simplified mass balance figure.

Change Approval
Team Lead: R. A. Kirkbride Randy A Kutetude Customer: P. J. Certa Pall Lu $813 / 04$
(1)

Manager: N.W. Kirch Solloeleay $8 / 3 / 2004$

Customer: N/A 
Table A-1. Assumptions Matrix. (19 Sheets)

Case name: Sr Solubility Model Test

\section{A1.1. Brief Description of Case}

Test the incorporation of a simple Sr solubility model into HTWOS. A simple schematic of the overall

Involves Model

Change That

Needs to be

Verified?

process is shown in Figure 1.

A simple schematic of the overall process is shown in Figure A-1.

\section{A2.0. Major Facilities}

\section{A2.1. New Waste Generation}

A2.1.1. New Waste Introduced Via 200 East Area

\begin{tabular}{|l|l|c}
\hline PUREX - yearly rate & $5 \mathrm{Kgal} /$ year & No \\
\hline B-Plant - yearly rate & No waste anticipated & No \\
\hline WESF - yearly rate & No waste anticipated & No \\
\hline 300 Area - yearly rate & 0 to $30 \mathrm{Kgal} /$ year & No \\
Flush for misc. waste & $44 \%$ & \\
RF & $94 \%$ & \\
\hline 400 Area & No wastes anticipated & No \\
\hline WSCF & No wastes anticipated & No \\
\hline 100 Area & No wastes anticipated from 100 N, 100-K Basin, & No \\
& $105-F$ Basin, or $105-$ Hasin & \\
\hline
\end{tabular}

\section{A2.1.2. New Waste Introduced Via 200 West Area}

\begin{tabular}{|c|c|c|}
\hline $\begin{array}{l}\text { 222-S Laboratory - yearly rate } \\
\text { Flush for misc. waste } \\
\text { WVRF }\end{array}$ & $\begin{array}{l}10 \mathrm{Kgal} / \text { year } \\
22 \% \\
99 \%\end{array}$ & No \\
\hline $\begin{array}{l}\text { T-Plant } \\
\text { Yearly rate (FY 2003) } \\
\text { Yearly rate (FY 2004 on) } \\
\text { Flush for misc. waste } \\
\text { WVRF } \\
\end{array}$ & $\begin{array}{l}17 \mathrm{Kgal} / \text { year } \\
3 \text { to } 14 \mathrm{Kgal} / \text { year } \\
22 \% \\
99 \% \\
\end{array}$ & No \\
\hline $\begin{array}{l}\text { PFP stabilization - not calculated in yearly } \\
\text { average dates } \\
\text { Total volume } \\
\quad \text { Flush } \\
\text { WVRF } \\
\end{array}$ & $\begin{array}{l}2003-2005 \\
37 \text { Kgal total } \\
22 \% \\
81 \% \\
\end{array}$ & No \\
\hline \multicolumn{3}{|l|}{ Tank Farm Waste Generations } \\
\hline $\begin{array}{l}\text { Tank Farms } \\
\text { Yearly Rate } \\
\text { WVRF }\end{array}$ & $\begin{array}{l}120 \mathrm{Kgal} / \text { year } \\
99 \%\end{array}$ & No \\
\hline
\end{tabular}

A2.2. Waste Treatment Plant

A2.2.1. Low-Activity Waste Processing

LAW feed delivery dates

Start delivery of the first LAW feed batch on 12/1/2009 $\quad$ No

and deliver remaining LAW feed as needed to keep the WTP operating within model constraints. The first LAW feed batch will be provided by a decant transfer of all supernatant in AY-102 (less ten-inches above the HLW solids) to the LAW feed receipt tanks. 
Table A-1. Assumptions Matrix. (19 Sheets)

\begin{tabular}{|c|c|c|}
\hline \multicolumn{2}{|c|}{ Case name: Sr Solubility Model Test } & \begin{tabular}{|c|} 
Involves Model \\
Change That \\
Needs to be \\
Verified?
\end{tabular} \\
\hline LAW Pretreatment Ramp Up & 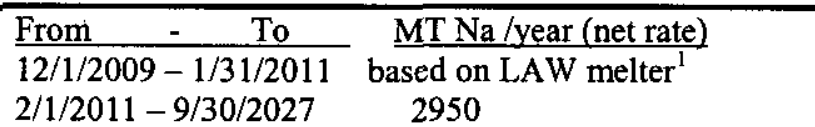 & No \\
\hline LAW Vitrification Ramp Up ${ }^{2}$ & 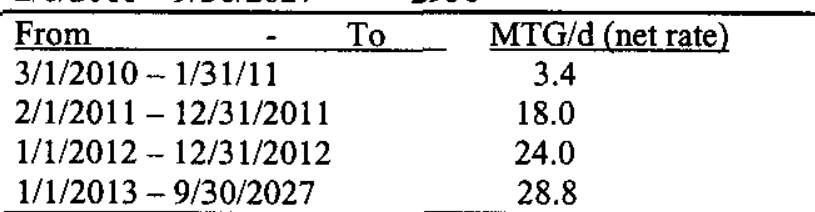 & No \\
\hline Complete Waste Processing & Goal is to complete waste processing by $9 / 30 / 2027$. & $\overline{\text { No }}$ \\
\hline \multicolumn{3}{|c|}{ A2.2.2. LAW Feed Receipt Tanks } \\
\hline LAW Feed Receipt Tank Use & $\begin{array}{l}1.5 \mathrm{Mgal} \text { Total Capacity; be capable of receiving } 1 \mathrm{Mgal} \\
\text { without interruption while feeding out of the remaining } \\
0.5 \mathrm{Mgal}\end{array}$ & No \\
\hline \multicolumn{3}{|c|}{ A2.2.3. LAW Pre-Treatment Process } \\
\hline LAW WTP Process Model & 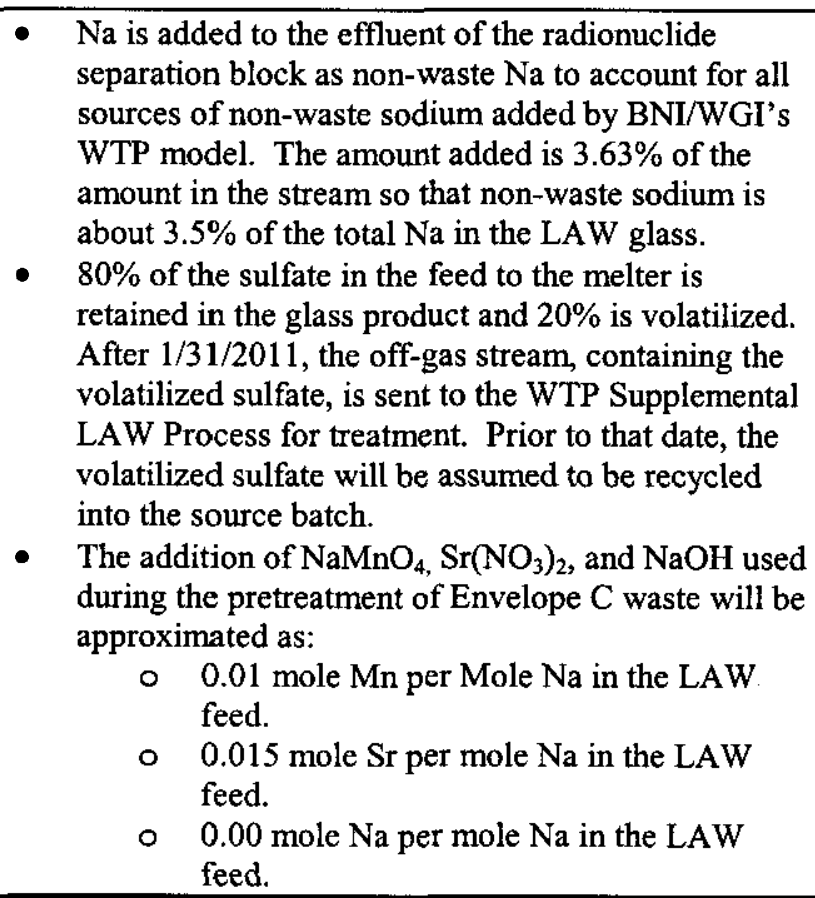 & No \\
\hline \multicolumn{3}{|c|}{ A2.2.4. ILAW Formulation and Packaging } \\
\hline ILAW Na $\mathrm{O}_{2} \mathrm{O}$ Loading & Gimpel Rule Rev. 4 & No \\
\hline ILAW Glass Density & $2.6 \mathrm{MT} / \mathrm{m}^{3}$ & No \\
\hline ILAW Package Net Mass & $6.0 \mathrm{MT}$ & No \\
\hline \multicolumn{3}{|c|}{ A2.2.5. ILAW Interim Storage Capacity } \\
\hline ILAW Interim Storage Capacit & No lag storage of ILAW in WTP. & No \\
\hline
\end{tabular}

\footnotetext{
${ }^{1} \mathrm{LAW}$ pretreatment will provide sufficient feed at the rate needed to operate the LAW melter.

${ }^{2}$ RPP System Plan, Rev. 2 (ORP-11242).
} 
RPP-21807 Rev. 0

Table A-1. Assumptions Matrix. (19 Sheets)

Case name: Sr Solubility Model Test

Involves Model

Change That

Needs to be

Verified?

\section{A2.2.6. High-Level Waste Processing}

\begin{tabular}{|c|c|c|c|}
\hline HLW feed delivery dates & \multicolumn{2}{|c|}{$\begin{array}{l}\text { Start delivery of the first batch group of HLW feed on } \\
12 / 15 / 2009 \text { and deliver remaining HLW feed as needed } \\
\text { to keep the WTP operating within model constraints. } \\
\text { The first batch group of HLW feed will be provided from } \\
\text { AY }-102 \text { by adding sufficient water to the decanted solids } \\
\text { to yield a solids loading between } 10 \text { and } 200 \text { grams } \\
\text { solids per liter of slurry ( } 150 \text { g/liter nominal). }\end{array}$} & No \\
\hline HLW Vitrification Ramp-up ${ }^{3}$ & $\begin{array}{l}\text { From }- \text { To } \\
5 / 17 / 2010-1 / 31 / 2011 \\
2 / 1 / 2011-12 / 31 / 2011 \\
1 / 1 / 2012-12 / 31 / 2012 \\
1 / 1 / 2013-9 / 30 / 2027\end{array}$ & $\begin{array}{l}\text { MTG/d (net rate) } \\
0.69 \\
3.0 \\
4.0 \\
5.4^{4} \\
\end{array}$ & No \\
\hline \multicolumn{4}{|c|}{ A2.2.7. HLW Feed Receipt Tanks } \\
\hline HLW Feed Receipt Tank Usage & 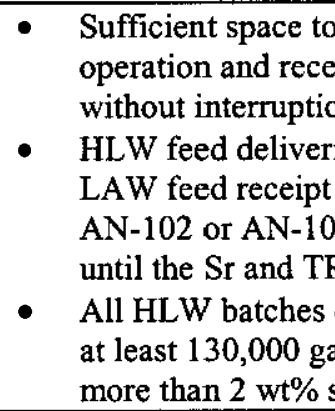 & $\begin{array}{l}\mathrm{d} \text { feed for } 60 \text { days of } \\
160,000 \text { gallons }\left(600 \mathrm{~m}^{3}\right) \\
\text { vill be suspended when the } \\
\text { s contain waste from either } \\
\text { segregate the LAW liquids } \\
\text { s removed. } \\
\text { rered after } 3 / 1 / 2018 \text { must be } \\
\text { s total volume and contain } \\
\text { s. }\end{array}$ & No \\
\hline
\end{tabular}

\footnotetext{
${ }^{3}$ River Protection Project System Plan, Rev. 2 (ORP-11242).

${ }^{4}$ This is the capacity estimated to be needed to complete processing all HLW into glass by 9/30/2027. This capacity may be adjusted at the modeler's discretion to complete the processing of all waste by 9/30/2027.
} 
Table A-1. Assumptions Matrix. (19 Sheets)

Case name: Sr Solubility Model Test

A2.2.8. HLW Pre-Treatment Process

HLW WTP Process Model

- The water wash factors in the TWINS on 5/14/2003

(or $\mathrm{Sr}$ model in the case of $\mathrm{Sr}$ ) will be used for partitioning waste into solid and liquid phases during retrieval and staging.

- The caustic leach factors in the TWINS on 5/14/2003 will be used as the basis for computing the caustic leach factors associated with each delivered batch of HLW solids and for the entrained solids.

- All HLW solids batches and entrained solids will be leached. One exception is that AN-102 or AN-107 solids will not be leached if those wastes are delivered as distinct LAW batches. ${ }^{5}$

- The amount of caustic added to the waste during the caustic leach will be determined as follows:

- Concentrate the HLW slurry to $20 \mathrm{wt} \%$ solids.

- Water wash.

- Add sufficient $19 \mathrm{M} \mathrm{NaOH}$ to result in an initial $\left[\mathrm{OH}^{-}\right]$concentration of $3.0 \mathrm{M}$, excluding all $\left[\mathrm{OH}^{-}\right]$in the water-washed slurry.

- Perform caustic-leaching reactions.

- The post-leach wash is performed with 22,000 gallons of water.

\section{A2.2.9. IHLW Formulation and Packaging}

\begin{tabular}{|c|c|c|}
\hline $\begin{array}{l}\text { Method for Estimating HLW Waste Oxide } \\
\text { Loading }\end{array}$ & $\begin{array}{l}\text { Glass Properties Model modified as follows. } \\
\text { - Increase the spinel liquidus temperature constraint } \\
\text { from } 1050^{\circ} \mathrm{C} \text { to } 1100^{\circ} \mathrm{C} \text {. } \\
\text { - Increase the viscosity constraint from } 5.5 \mathrm{~Pa} \bullet \text { s to } 10 \\
\text { Pa॰s. } \\
\text { Increase the } \mathrm{Cr}_{2} \mathrm{O}_{3} \text { constraint from } 0.5 \mathrm{wt} \% \text { to } 1.0 \\
\text { wt\%. }\end{array}$ & No \\
\hline IHLW Glass Density & $2.7 \mathrm{MT} / \mathrm{m}^{3}$ & No \\
\hline IHLW Canister Net Mass & $.0 \quad 3.2 \mathrm{MT}$ (thin-walled canister) & No \\
\hline \multicolumn{3}{|l|}{ A2.2.10. IHLW Interim Storage } \\
\hline IHLW Interim Storage Capacity & $\begin{array}{l}22 \text { canisters of IHLW can be stored in the WTP before } \\
\text { having to ship canisters to an interim storage site on the } \\
\text { Hanford Site. }\end{array}$ & No \\
\hline
\end{tabular}

\footnotetext{
${ }^{5}$ When AN-102 or AN-107 wastes delivered as distinct LAW batches, the entrained solids are not leached because of the Sr/TRU precipitation step.
} 
RPP-21807 Rev. 0

Table A-1. Assumptions Matrix. (19 Sheets)

Case name: Sr Solubility Model Test

Involves Model

Change That

Needs to be

Verified?

\section{A2.2.11. Supplemental LAW Treatment}

\begin{tabular}{|c|c|c|}
\hline Supplemental LAW Processing Ramp-up & $\begin{array}{lll}\text { From }- & \text { To } & \text { MT Na/year } \\
1 / 31 / 2011-9 / 30 / 2027 & (2950-\text { LAW Vit rate })^{6}\end{array}$ & No \\
\hline Product and Packaging & $\begin{array}{l}\text { Two sets of product assumptions will be used outside of } \\
\text { the HTWOS model to estimate product mass, volume } \\
\text { and package count. } \\
\text { Bulk-Vitrification } \\
\text { - } \quad \text { Assume a } 20 \mathrm{wt} \% \text { waste } \mathrm{Na}_{2} \mathrm{O} \text { loading. } \\
\text { - } \quad \text { Glass density is } 2.74 \mathrm{MT} / \mathrm{m}^{3} \text {. } \\
\text { - } \quad \text { Packaged in } 35 \mathrm{~m}^{3} \text { roll-off boxes, each filled with } \\
58 \mathrm{MT} \text { glass. External volume of box is } 1,920 \mathrm{ft}^{3} \\
\text { ( } 8 \mathrm{ft} \text { by } 10 \mathrm{ft} \text { by } 24 \mathrm{ft}, \sim 54.4 \mathrm{~m}^{3} \text { ). } \\
\text { Steam Reformer } \\
\text { - } \quad \text { Assume a } 19.8 \mathrm{wt} \% \mathrm{Na}_{2} \mathrm{O} \text { loading } \\
\text { - } \quad \text { Bulk product density is } 1.0 \mathrm{MT} / \mathrm{m}^{3} \\
\text { - Packaged in } 2.3 \mathrm{~m}^{3} \text { (standard } \mathrm{ILAW} \text { ) containers. } \\
\text { External volume of package is } 1.162 \text { times the } \\
\text { volume of glass contained in the package. }\end{array}$ & No \\
\hline
\end{tabular}

${ }^{6}$ The WTP Supplemental LAW process capacity is calculated as the difference between the LAW pretreatment capacity (2950 MT Na per yr) and the LAW melter capacity expressed in MT Na per yr, and depends on the glass formulation for specific LAW batches. 
RPP-21807 Rev. 0

Table A-1. Assumptions Matrix. (19 Sheets)

Case name: Sr Solubility Model Test

Involves Model

Change That

Needs to be

Verified?

\section{A2.3. Supplemental Treatment}

\section{A2.3.1. TRU/LLW Sludge Packaging}

Contact-Handled Sludge Packaging

- The TRU packaging facility will be available and

begin packaging operations will begin on

$10 / 28 / 2004$. The nameplate capacity of the facility

is 7,200 gallons of SST waste per day. ${ }^{7}$

- Wastes will be retrieved from the B-200 series SSTs

to support operation at $40 \%$ of the nameplate

capacity.

- There will be a 30 day break in operation to redeploy the facility in the 200 West Area; then wastes from the T-200 series SSTs will be retrieved and delivered to the facility to support operation at $40 \%$ of the nameplate capacity.

- Then waste from tanks T-111, T-112, T-104, and $\mathrm{T}-110$ will be retrieved, according to the schedule in Table A-14 in Section A3.3 and delivered to the facility to support operation at $50 \%$ of the nameplate capacity.

- There will be a 30 day break in operation to redeploy the facility in the 200 East Area; then wastes from tanks B-110 and B-111 will be retrieved and delivered to the facility to support operation at $50 \%$ of the nameplate capacity.

- All the waste from the B-200 and T-200 series SSTS, T-110, and T-111 will be retrieved without impact to DST space.

- It is assumed that all the SST wastes can be packaged as contact-handled TRU or disposed of via the TRU packaging system.

- There will be no water or waste sent to the DST system.

${ }^{7}$ This volumetric processing rate is equivalent to an estimated mass processing rate of $20.4 \mathrm{MT}$ solids/day assuming 25 volume \% solids and a solids density of $3 \mathrm{MT} / \mathrm{m}^{3}$. HTWOS will use the mass processing rate and the modeler has the discretion to adjust the mass processing rate to match processing durations based on the volumetric processing rate. 
Table A-1. Assumptions Matrix. (19 Sheets)

Case name: Sr Solubility Model Test

Involves Model

Change That

Needs to be

Verified?

Remote-Handled Sludge Packaging -

AW-103, AW-105, and SY-102
- A remote TRU sludge packaging facility will begin Yes operation on 7/1/2012 and be sized to complete the packaging of waste from tanksAW-103, AW-105, and SY-102 by $3 / 31 / 2015$.

- Supernatant liquid will be decanted from tank AW-103 in August 2011. The waste solids in tank AW-103 will be washed four times over a nine month period starting $9 / 1 / 2011$ using 273,000 gallons of $0.01 \underline{\mathrm{M} \mathrm{NaOH}}$ solution each time. After each wash, the solids are settled to $40 \mathrm{wt} \%$ before decanting the wash solution for feed to the evaporator. The first wash of $\mathrm{AW}-103$ waste solids is assumed to dissolve the saltcake portion. Existing water wash factors (or $\mathrm{Sr}$ model in the case of $\mathrm{Sr}$ ) will be applied to estimate the overall wash effectiveness.

- Supernatant liquid will be decanted from tank $A W-105$ in September 2012. The waste solids in tank AW-105 will be washed four times over a nine-month period starting 10/1/2012 using 263,000 gallons of $0.01 \mathrm{M} \mathrm{NaOH}$ solution each time. After each wash, the solids are settled to $40 \mathrm{wt} \%$ before decanting the wash solution for feed to the evaporator. The first wash of $\mathrm{AW}-105$ waste solids is assumed to dissolve the saltcake portion. Existing water wash factors (or Sr model in the case of Sr) will be applied to estimate the overall wash effectiveness.

- Supernatant liquid will be decanted from tank SY -102 by $10 / 30 / 2013$. The SY -102 solids will be washed three times over a nine month period starting by $11 / 1 / 2013$ using 290,000 gallons of $0.01 \mathrm{M} \mathrm{NaOH}$ solution each time. After each wash, the solids are settled to $40 \mathrm{wt} \%$ before decanting the wash solution for feed to the evaporator. The first wash of SY-102 waste solids is assumed to dissolve the saltcake portion. Existing water wash factors (or $\mathrm{Sr}$ model in the case of $\mathrm{Sr}$ ) will be applied to estimate the overall wash effectiveness. (Note: The solids in SY-102 may be moved to AW-103 for washing, after the washed AW-103 solids are delivered for packaging, if the cross-site transfer does not delay operation of the packaging facility.)

- Carrier liquids will be separated from the solids in the packaging facility and transferred to the DST system for concentration and eventual delivery as LAW feed. ${ }^{8}$

- The washed solids are assumed to be remote handled for packaging. 
Table A-1. Assumptions Matrix. (19 Sheets)

Case name: Sr Solubility Model Test

Involves Model

Change That

Needs to be

Verified?

\section{A2.3.2. Non-WTP Supplemental LAW Processing}

\begin{tabular}{|c|c|c|}
\hline Process and Ramp-Up & $\begin{array}{l}\text { A demonstration facility will be located in the } \\
200 \text { West Area (west of S-Farm) and be operated for } \\
18 \text { months starting on } 10 / 1 / 2004 \text { to process } 300 \mathrm{MT} \\
\text { of Na from tank S-109. } \\
\text { The demonstration facility will be fed directly from } \\
\text { S-109 with no solids entrained out of S- } 109 \text {. The } \\
\text { feed will be delivered at } 5 \mathrm{M} \mathrm{Na} \text {. The S-109 waste } \\
\text { retrieval will be controlled to limit the total activity } \\
\text { in the retrieved waste to } 0.0062 \mathrm{Ci} \text { per liter (at the } \\
5 \mathrm{M} \text { Na feed concentration). } \\
\text { The production process will be located in the } \\
200 \text { East Area. } \\
\text { The production facility starts operating after } \\
1 / 31 / 2011 \text { and operates at the rate needed to process } \\
\text { at least } 4500 \mathrm{MT} \text { of Na by } 9 / 30 / 2027 \text {. } \\
\text { Low-Cs waste in the } 200 \mathrm{West} \text { Area will be moved } \\
\text { cross-site to feed the process when dedicated DST } \\
\text { space is available to transfer low-Cs waste without } \\
\text { contamination (through SY-101 in to an East Area } \\
\text { DST used as a feed tank). }\end{array}$ & No \\
\hline Feed Staging and Solids Return & $\begin{array}{l}\text { The low-Cs tanks that are candidates for feed are } \\
\text { identified in Table A-14 in Section A3.3. Other } \\
\text { low-Cs tanks may be substituted with the } \\
\text { concurrence of the Requestor. } \\
\text { - All entrained solids are separated from the waste } \\
\text { liquids in the supplemental treatment facility (in a } \\
\text { way to minimize the Na returned to the DST system) } \\
\text { before treatment of the liquids and are returned } \\
\text { directly to an appropriate DST (AN-106 or AY-101) } \\
\text { as } 20 \text {-wt\% slurry. } \\
\text { Details concerning feed batch size and process } \\
\text { control strategy have not been established. } \\
\text { Therefore, for simplicity, assume that the process } \\
\text { operates as a continuous process. }\end{array}$ & No \\
\hline
\end{tabular}


Table A-1. Assumptions Matrix. (19 Sheets)

\begin{tabular}{|c|c|c|}
\hline \multicolumn{2}{|c|}{ Case name: Sr Solubility Model Test } & \multirow{2}{*}{\begin{tabular}{|c} 
Involves Model \\
$\begin{array}{c}\text { Change That } \\
\text { Needs to be } \\
\text { Verified? }\end{array}$ \\
No
\end{tabular}} \\
\hline Product and Packaging & $\begin{array}{l}\text { Three sets of product assumptions will be used outside of } \\
\text { the } \mathrm{HTWOS} \text { model to estimate product mass, volume } \\
\text { and package count. } \\
\text { Bulk-Vitrification } \\
\text { - } \quad \text { Assume a } 20 \mathrm{wt} \% \text { waste } \mathrm{Na}_{2} \mathrm{O} \text { loading. } \\
\text { - } \quad \text { Glass density is } 2.74 \mathrm{MT} / \mathrm{m}^{3} \text {. } \\
\text { - } \quad \text { Packaged in } 35 \mathrm{~m}^{3} \text { roll-off boxes, each filled with } \\
58 \mathrm{MT} \text { glass. External volume of box is } 1,920 \mathrm{ft}^{3} \\
\left.\text { ( } 8 \mathrm{ft} \text { by } 10 \mathrm{ft} \text { by } 24 \mathrm{ft}, \sim 54.4 \mathrm{~m}^{3}\right) . \\
\text { Steam Reformer } \\
\text { - } \quad \text { Assume a } 19.8 \mathrm{wt} \% \mathrm{Na}_{2} \mathrm{O} \text { loading } \\
\text { - } \quad \text { Bulk product density is } 1.0 \mathrm{MT} / \mathrm{m}^{3} \\
\text { - } \quad \text { Packaged in } 2.3 \mathrm{~m}^{3} \text { (standard ILAW) containers. } \\
\text { External volume of package is } 1.162 \text { times the } \\
\text { volume of glass contained in the package. }\end{array}$ & \\
\hline \multicolumn{3}{|l|}{ A2.4. Waste Disposal Sites } \\
\hline $\begin{array}{l}\text { ILAW Facility Need Dates } \\
\text { (Integrated Disposal Facility; IDF) }\end{array}$ & $\begin{array}{l}\text { To be determined from production schedule assuming no } \\
\text { WTP lag storage of ILAW. This assumes that the ILAW } \\
\text { produced by the Supplemental Treatment demonstration } \\
\text { can be stored until the IDF is available. }\end{array}$ & No \\
\hline $\begin{array}{l}\text { IHLW Facility Need Dates } \\
\text { (Project W-464) }\end{array}$ & $\begin{array}{l}\text { The need date for IHLW interim storage facility } \\
\text { (the Canister Storage Building) will be the date on which } \\
\text { the } 1^{\text {st }} \text { IHLW is produced }(5 / 17 / 2010) \text {. The demand for } \\
\text { interim storage space will be established assuming that } \\
22 \text { canisters of WTP-provided IHLW is used. The } \\
\text { shipping date of IHLW to Yucca will be the date on } \\
\text { which the Canister Storage Building is full ( } 880 \text { canisters } \\
+22 \text { canisters in WTP-provided lag storage), but no } \\
\text { earlier than September } 30,2012 \text {. Assume shipping } \\
\text { keeps up with production once shipping begins. }\end{array}$ & No \\
\hline \multicolumn{3}{|c|}{ A2.5. Cesium and Strontium Capsule Processing } \\
\hline Cesium and Strontium Capsules & $\begin{array}{l}\text { Cesium and strontium capsules are disposed separately } \\
\text { by RL and not incorporated into HLW glass in the WTP }\end{array}$ & No \\
\hline
\end{tabular}


RPP-21807 Rev. 0

Table A-1. Assumptions Matrix. (19 Sheets)

\begin{tabular}{|c|c|c|}
\hline \multicolumn{2}{|l|}{ Case name: Sr Solubility Model Test } & $\begin{array}{l}\text { Involves Model } \\
\text { Change That } \\
\text { Needs to be } \\
\text { Verified? }\end{array}$ \\
\hline \multicolumn{3}{|l|}{ A3.0. Retrieval and Closure } \\
\hline \multicolumn{3}{|l|}{ A3.1. SST Interim Stabilization } \\
\hline $\begin{array}{l}\text { Saltwell liquid pumping } \\
\text { Volume remaining on } 10 / 1 / 2003 \\
\text { West Area receiver tank } \\
\text { Pumping completion } \\
\text { Dilution/flush for pumping }\end{array}$ & $\begin{array}{l}\sim 56 \mathrm{Kgal} \\
\text { SY-101 or SY }-102 \\
\text { FY } 2004 \\
28-275 \%\end{array}$ & No \\
\hline \multicolumn{3}{|c|}{ A3.2. SST Tri-Party Agreement Milestones } \\
\hline SST TPA Milestone Dates & See Table A-14 in Section A3.3. & No \\
\hline \multicolumn{3}{|l|}{ A3.3. SST Retrieval Sequence Basis } \\
\hline Retrieval sequence basis & $\begin{array}{l}\text { Table A-14 in Section A3.3 provides the sequence and } \\
\text { schedule for SST retrievals out through the end of } \\
\text { FY 2008. This sequence and schedule was developed } \\
\text { with considerations of risk reduction. The sequence and } \\
\text { schedule for retrieval of waste from the remaining SSTs } \\
\text { will be determined by the model based on algorithms } \\
\text { that consider risk measures, DST space availability, and } \\
\text { WTP feed requirements. } \\
\text { Estimates for the as-retrieved volume of SST wastes } \\
\text { from selected tanks are also given in Table A-14. }\end{array}$ & No \\
\hline \multicolumn{3}{|l|}{ A3.4. Waste Retrieval Facilities } \\
\hline Waste Retrieval Facility Availability Dates & $\begin{array}{l}\text { B-Complex WRF: } 6 / 1 / 2018 \\
\text { T-Complex WRF: } 6 / 1 / 2018 \\
\text { Wastes retrieved from tanks in the B or T complexes } \\
\text { before the WRFs are available will be at lower insoluble } \\
\text { solids loadings as defined in the Retrieved Waste } \\
\text { Composition assumptions (see Section A3.8). }\end{array}$ & No \\
\hline \multicolumn{3}{|l|}{ A3.5. SST Farm Upgrades } \\
\hline $\begin{array}{l}\text { Availability Dates for Tank Farms } \\
\text { Upgrades }\end{array}$ & $\begin{array}{l}\text { Any SST farm upgrades needed to support the retrieval } \\
\text { of SST waste will be completed before the retrieval dates } \\
\text { projected by the HTWOS model. }\end{array}$ & No \\
\hline
\end{tabular}


Table A-1. Assumptions Matrix. (19 Sheets)

Case name: Sr Solubility Model Test

Involves Model

Change That

Needs to be

Verified?

\section{A3.6. Constraints on Simultaneous Retrievals}

Simultaneous retrieval

- The most limiting condition(s) resulting from

No application of the following constraints: ${ }^{9}$

- Retrieval and transfer systems in the NE and NW quadrants can support a maximum of 6 simultaneous retrievals in each tank farm and a total of six simultaneous retrievals in each quadrant (after the WRFs are constructed).

- Retrieval and transfer systems in the SE and SW quadrants can support a maximum of 2 simultaneous retrievals in each tank farm and a total of two simultaneous retrievals in that quadrant.

SE - A, AX, and C farms

NE - B, BX, and BY farms

$S W-S, S X$, and $U$ farms

NW - T, TX, and TY farms

- A maximum of 7 total simultaneous retrievals can be performed at one time. (This assumes that labor resources are available.)

- The waste from up to two SSTs may be retrieved to one DST at one time.

- The waste from one only SST may be retrieved into one WRF tank at a time.

- Constraints also apply to retrievals going directly from SSTs to supplemental treatment processes.

\section{A3.7. Retrieval Rates}

- Minimum retrieval durations are given in Section A3.7 and based on proposed project schedules or technologies to be used to retrieve the waste. 
Table A-1. Assumptions Matrix. (19 Sheets)

Case name: Sr Solubility Model Test

Involves Model

Change That

Needs to be

Verified?

\section{A3.8. Retrieved Waste Composition}

Retrieval Solution Requirements

- The amount of retrieval solution needed to retrieve

Yes the waste from SSTs listed in Table A-14 in Section A3.3 will be determined as the amount need to achieve the total retrieved volume given in the table after the application of water wash factors (or Sr model in the case of Sr).

- The amount of retrieval solution needed to retrieve wastes from the $S, S X$, and $U$ farm SSTs not listed in Table A-14 will be determined as the amount needed to result in a $\mathrm{Na}$ concentration $\leq 5 \underline{\mathrm{M}}$ and an insoluble solids concentration $\leq 5 \mathrm{wt} \%$ ( 3.5 volume $\%$ ) after the application of wash factors (or $\mathrm{Sr}$ model in the case of $\mathrm{Sr}$ ).

- The amount of retrieval solution needed to retrieve wastes from SSTs in the B or T farm complex before the WRFs are available will be determined as the amount needed to result in a $\mathrm{Na}$ concentration $\leq 5 \underline{\mathrm{M}}$ and an insoluble solids concentration $\leq 5 \mathrm{wt} \%$ after the application of wash factors (or $\mathrm{Sr}$ model in the case of $\mathrm{Sr}$ ).

- The amount of retrieval solution needed to retrieve wastes from SSTs in the B or T farm complex after the WRFs are available will be determined as the amount needed to result in a $\mathrm{Na}$ concentration $\leq 5 \underline{\mathrm{M}}$ and an insoluble solids concentration $\leq 10 \mathrm{wt} \%$ after the application of wash factors (or Sr model in the case of $\mathrm{Sr}$ ).

- The amount of retrieval solution needed to retrieve wastes from all other SSTs will be determined as the amount needed to result in a $\mathrm{Na}$ concentration $\leq 5 \underline{\mathrm{M}}$ and an insoluble solids concentration $\leq 10 \mathrm{wt} \%$ after the application of wash factors (or Sr model in the case of $\mathrm{Sr}$ ).

A3.9. Retrieval System Reuse

Retrieval System Availability

- A sufficient number of retrieval systems are available.

- Retrieval systems will be reused when cost effective.

A4.0. Waste Feed Operations

A4.1. Waste Inventory 
Table A-1. Assumptions Matrix. (19 Sheets)

Case name: Sr Solubility Model Test

\section{A4.1.1. Initial Inventory}

\begin{tabular}{|l|l|l|}
\hline Date that BBI quarterly update was issued & $\begin{array}{l}\text { Starting tank inventory represents waste inventory as of } \\
6 / 30 / 2003 . \text { This will be referred to as the FY 2004 } \\
\text { inventory (or as the October 2003 inventory) and is } \\
\text { based on BBI data downloaded from TWINS on about } \\
10 / 22 / 2003 . \text { Adjustments were made in the HTWOS } \\
\text { model for historical transfers through 9/30/2003. }\end{array}$ & No \\
\hline $\begin{array}{l}\text { IMUST waste } \\
\text { Total volume (2011-15) }\end{array}$ & $500 \mathrm{Kgal}$ total & No \\
\hline
\end{tabular}

\section{A4.2.1. Sodium Hydroxide Additions}

Caustic addition

- Planned Additions

- Caustic Rules for SST Retrievals
- No near-term additions are planned. Future evaluations may show the need for caustic additions.

- Liquids associated with sludge retrievals need to have at least $0.05 \underline{\mathrm{M}}$ free $\mathrm{OH}$. Saltcake retrievals do not require $\mathrm{NaOH}$ addition because waste in DSTs contains sufficient $\mathrm{OH}$ as a buffer.

\section{A4.2.2. Flush Volumes}

Table A-16 in Section A4.2.2 provides the flush volumes used in the HTWOS model.

\section{A4.2.3. Minimum DST Level}

- Liquids or slurries can be removed down to within 12 inches above the bottom of a DST.

- Wastes can be removed down to the bottom of a DST during final cleanout.

- Supernatants can be pumped down to within 10 inches of a settled solids layer.

- SY-101 can only be pumped down to 100 inches ( $275 \mathrm{Kgal}$ ) between now and $10 / 1 / 2013$. After that date, the transfer pump will be replaced and the waste can be pumped down to 12 inches.

- SY-102 can only be pumped down to 200 inches $(550 \mathrm{Kgal})$ until the solids are washed before delivery for TRU packaging. After the solids are washed the waste can be pumped down to within 12 inches.

- The AZ/AY farm tanks can be pumped down below 64 inches if the annulus ventilation is shut down. The annulus ventilation will be shut down when necessary to deliver feed to the WTP allowing the waste to be pumped down within 12 inches of the bottom. 
Table A-1. Assumptions Matrix. (19 Sheets)

\begin{tabular}{|c|c|c|}
\hline \multicolumn{2}{|c|}{ Case name: Sr Solubility Model Test } & $\begin{array}{l}\text { Involves Model } \\
\text { Change That } \\
\text { Needs to be } \\
\text { Verified? }\end{array}$ \\
\hline \multicolumn{3}{|c|}{ A4.2.4. Maximum DST Level } \\
\hline Maximum DST Levels & $\begin{array}{l}\text { Raise the DST fill limits according to the schedule given } \\
\text { in Table A-18 in Section A4.2.3 of these assumptions. }\end{array}$ & No \\
\hline \multicolumn{3}{|c|}{ A4.2.5. Tank Solids Level } \\
\hline Solids Settling Endpoint & Insoluble solids can be settled to $40 \mathrm{wt} \%$ within 30 days. & No \\
\hline \multicolumn{3}{|c|}{ A4.2.6. Tank Space Allocation } \\
\hline Space Allocation Categories & $\begin{array}{l}\text { Use the categories and reasoning given in Table A-19 in } \\
\text { Section A4.2.6 to allocate and track head space above } \\
\text { the waste in the DSTs. }\end{array}$ & No \\
\hline DST Usage & $\begin{array}{l}\text { WTP Feed Staging tanks: }{ }^{10} \\
\text { AN-101, AN-102, AN-103, AN-104, AN-105, AN-107, } \\
\text { AP-101, AP-102, AP-103, AP-104, AP-105, AP-106, } \\
\text { AP-108, AW-101, AY-101, AY-102, AZ-101, and } \\
\text { AZ-102 } \\
\text { WTP Alternative (Back-up) HLW Feed Staging } \\
\text { tanks: } \\
\text { AN-103, AN-104 (cross-site receiver), and AN-105. At } \\
\text { the modelers' discretion, other DSTs equipped with dual } \\
\text { mixer pumps can be used to store and stage HLW feed. } \\
\text { Slurry Transfer Limitations: } \\
\text { Use AZ, AY, and AN farms, primarily for staging HLW } \\
\text { solids. Try to avoid staging solids through AP or AW } \\
\text { farms after retrieving the solids currently in those farms. } \\
\text { Supplemental Sludge Treatment Process Feed } \\
\text { Staging Tanks: } \\
\text { AW-103, AW-105, and SY-102 } \\
\text { Non-WTP Supplemental LAW Treatment DST } \\
\text { Usage: } \\
\text { Provide feed directly from East Area SSTs to the } \\
\text { treatment process. Transfer low-Cs wastes from the } \\
\text { West Area when sufficient DST space is available } \\
\text { transfer cross-site without contamination and to provide } \\
\text { a dedicated feed tank. Entrained solids separated in the } \\
\text { process are returned to AN-106 or AY-101 depending on } \\
\text { space availability. }\end{array}$ & No \\
\hline
\end{tabular}


Table A-1. Assumptions Matrix. (19 Sheets)

\begin{tabular}{|c|c|c|}
\hline \multicolumn{2}{|l|}{ Case name: Sr Solubility Model Test } & \begin{tabular}{|c} 
Involves Model \\
Change That \\
Needs to be \\
Verified?
\end{tabular} \\
\hline $\begin{array}{l}\text { Emergency Space and LAW or HLW Waste } \\
\text { Return Space } \\
\text { - TFC Emergency Space and } \\
\text { Emergency Returns from WTP } \\
\text { - LAW or HLW Non-Emergency } \\
\text { Process Returns from WTP } \\
\text { - Contingency space }\end{array}$ & $\begin{array}{l}\text { Emergency Space and Emergency Returns will be raised } \\
\text { from } 1.14 \mathrm{Mgal} \text { to } 1.235 \mathrm{Mgal} \text { on } 6 / 30 / 2004 \text {, and will be } \\
\text { allocated as shown below: } \\
\text { - } 1.235 \mathrm{Mgal} \text { total } \\
\text { - None } \\
\text { - None }\end{array}$ & No \\
\hline WTP Returns (to the DST system) & $\begin{array}{l}\text { No waste streams or wastewaters are returned to DST } \\
\text { system from the WTP. }\end{array}$ & No \\
\hline \multicolumn{3}{|c|}{ A4.2.7. Waste Segregation or Blending } \\
\hline $\begin{array}{l}\text { Waste Segregation } \\
\text { - Store concentrated waste on NCRW } \\
\text { solids } \\
\text { - Store concentrated waste on NCAW } \\
\text { solids } \\
\text { - High-organic Content Wastes }\end{array}$ & $\begin{array}{l}\text { No wastes may be added to AW-103 and AW-105 } \\
\text { until sludge is removed for delivery to a packaging } \\
\text { facility. } \\
\text { AZ-102 supernatant blended with other wastes, } \\
\text { concentrated waste stored on top of AZ-102 solids. } \\
\text { AN-102 and AN-107 have been identified as high- } \\
\text { organic wastes (Envelope C); avoid creating more } \\
\text { Envelope C waste where possible. }\end{array}$ & No \\
\hline Blending & $\begin{array}{l}\text { - There is no deliberate blending of waste to optimize } \\
\text { WTP feeds other than the blending of AZ-102 } \\
\text { supernatant to reduce sulfate, and the consolidation } \\
\text { of AP- } 101 \text { into AY- } 102 \text {. Incidental blending that } \\
\text { occurs as waste is moved through the system is } \\
\text { relied on to provide benefits such as a significant } \\
\text { reduction in HLW glass quantities. } \\
\text { - Constrain the blending of AZ-102 supernate to start } \\
\text { after } 11 / 1 / 04 \text { and complete the blending by } \\
12 / 31 / 05 \text {, if possible. } \\
\text { Remove the supernatant from AY-102, concentrate } \\
\text { the waste in AP-101, and place the concentrated } \\
\text { AP-101 waste on top of AY- } 102 \text { solids. }\end{array}$ & No \\
\hline \multicolumn{3}{|l|}{ A4.2.8. Availability of DST Space } \\
\hline DST Integrity & No DST failures or replacements are assumed. & No \\
\hline \multicolumn{3}{|l|}{ A4.2.9. Space Optimization } \\
\hline $\begin{array}{l}\text { Tank Space Options Incorporated } \\
\text { (M-46-21 options) }\end{array}$ & $\begin{array}{l}\text { - Concentrate waste to save space. } \\
\text { - Release the ORP restriction on the use of the WTP } \\
\text { feed restricted space. } \\
\text { - Allocate only } 1.235 \mathrm{Mgal} \text { as emergency space. } \\
\text { - Implement tank level increases detailed in } \\
\text { Section A4.2.4. }\end{array}$ & No \\
\hline \multicolumn{3}{|c|}{ A4.2.10. Aging Waste Farm Condensates } \\
\hline & $\begin{array}{l}\text { HTWOS does not account for in-tank evaporation from } \\
\text { or the recycle back to the aging waste tanks. }\end{array}$ & No \\
\hline
\end{tabular}


Table A-1. Assumptions Matrix. (19 Sheets)

Case name: Sr Solubility Model Test

Involves Model

Change That

Needs to be

Verified?

A4.2.11. Common Use of Transfer Lines

\begin{tabular}{|c|c|c|}
\hline & $\begin{array}{l}\text { There are no restrictions on the subsequent use of } \\
\text { transfer lines based on waste types (HLW, LAW, TRU, } \\
\text { and LLW) and chemistries. }\end{array}$ & No \\
\hline \multicolumn{3}{|l|}{ A4.2.12. Waste Transfer Routes } \\
\hline $\begin{array}{l}\text { Essential Drawings for DST Waste Transfer } \\
\text { System }\end{array}$ & $\begin{array}{l}\text { H-14-104175, Rev. } 18 \\
\text { - H-14-104176, Rev. } 12 \\
\end{array}$ & No \\
\hline \multicolumn{3}{|l|}{ A4.2.13. Waste Transfers } \\
\hline Cross-site Transfer Rate & $\begin{array}{l}\text { Wastes transferred cross-site through the supernatant } \\
\text { line can be transferred at rates between } 50 \text { and } \\
60 \text { gallons per minute. } \\
\text { Wastes transferred cross-site through the slurry line } \\
\text { can be transferred at rates between } 100 \text { and } \\
120 \text { gallons per minute. }\end{array}$ & No \\
\hline SST Retrievals & $\begin{array}{l}\text { Wastes retrieved from the SSTs will be retrieved at the } \\
\text { capacity of the retrieval system as defined by the } \\
\text { minimum durations when DST space is available. }\end{array}$ & No \\
\hline DST Transfer Rate & $\begin{array}{l}\text { Wastes can be transferred between DSTs or to the WTP } \\
\text { at a rate of } 140 \text { gallons per minute (excluding cross-site } \\
\text { transfers). }\end{array}$ & No \\
\hline Transfer Durations & $\begin{array}{l}\text { Waste transfer durations will be calculated by dividing } \\
\text { the total volume being transferred by the transfer rate. }\end{array}$ & No \\
\hline Transfer System Set-up Time & $\begin{array}{l}\text { There is a 5-day delay between subsequent uses of } \\
\text { transfer routes having common components starting on } \\
11 / 1 / 2007 \text { to account for the closeout of one transfer } \\
\text { route and the establishment of another route. }\end{array}$ & No \\
\hline \multicolumn{3}{|l|}{ A4.3. 242-A Evaporator } \\
\hline \multicolumn{3}{|l|}{ A4.3.1. Evaporator Availability } \\
\hline $\begin{array}{l}\text { 242-A Evaporator Shutdown \& New } \\
\text { Evaporator Availability } \\
\text { Outage Schedule [FY(Duration in months)] }\end{array}$ & $\begin{array}{l}\text { - 242-A Evaporator is available until 9/30/2018 } \\
\text { - No tank farm evaporator is available after } 10 / 1 / 2018 \\
\text { to support DST space management. } \\
\text { - } 2003(3), 2004(4), 2005(6) \text {, and } 2006(3) \text {. } \\
\end{array}$ & No \\
\hline \multicolumn{3}{|l|}{ A4.3.2. Evaporator Operation } \\
\hline $\begin{array}{ll}\text { - } & \text { Training Volume } \\
\text { - } & \text { Average Evaporation Rate } \\
\text { - } & \text { Bottoms Set Point }(\mathrm{g} / \mathrm{mL}) \\
\text { - } & \text { Feed Staging Duration } \\
\text { - } & \text { Yearly Evaporation of Waste } \\
\text { - } & \text { SST wastes evaporated }\end{array}$ & $\begin{array}{ll}\text { - } & 50 \mathrm{Kgal} \text { of water is evaporated every } 2 \text { years to train } \\
& \text { personnel } \\
- & 500 \mathrm{Kgal} / \text { month } \\
- & 1.47^{11} \\
- & 3 \text { months minimum; }{ }^{12} \\
- & \text { Yes } \\
- & \text { Evaporate retrieved waste as needed to manage DST } \\
& \text { space until the WTP starts. }\end{array}$ & No \\
\hline
\end{tabular}


Table A-1. Assumptions Matrix. (19 Sheets)

Case name: Sr Solubility Model Test

Involves Model

Change That

Needs to be

Verified?

\section{A4.3.3. Waste Volume Reduction}

Waste Volume Reduction Facto

Water is removed until the specific gravity set point is reached (as calculated by algorithms within the model).

\section{A4.3.4. ETF and LERF}

- Effluent Treatment Facility

- Total treatment capacity

- Rate for evaporator condensate

- LERF Capacity

A4.4. Waste Feed Delivery

A4.4.1. LAW Feed Delivery Plans

LAW Feed Delivery Sequence and

Envelope Designation ${ }^{13}$,

Source Tank (Envelope)

AY-102 (containing concentrated AP-101; A/D)

- $24 \mathrm{Mgal} / \mathrm{year}$

- $5 \mathrm{Mgal} /$ year

- $\quad 7.8 \mathrm{Mgal}$

1-3 tanks from AP-Farm (A)

AN-104 (A)

AN-102 (C)

AN-105 (A)

AN-107 (C)

SY-101 (A)

AN-103 (A)

AW-101(A)

Continue with liquid wastes made available from SST

retrieval.

A4.4.2. LAW Feed Specifications

Delivered LAW feed compositions are compared to BNI contract Specification 7 to assess envelope compliance.

\section{A4.4.3. LAW Entrained Solids}

Entrained Solids Quantity
- $0.5 \mathrm{wt} \%$ solids are entrained in decanted supernatants.

- Supernatant liquids from dissolving salts will entrain the same solids concentration as exists in the tank after dissolution up to a maximum of $2 \mathrm{wt} \%$.

Entrained Solids Composition
Entrained solids have the same composition as the average composition of solids in the tank.
No

No 
Table A-1. Assumptions Matrix. (19 Sheets)

Case name: Sr Solubility Model Test

Involves Model

Change That

Needs to be

Verified?

\section{A4.4.4. HLW Feed Delivery Plans}

HLW Feed Delivery Sequence and

Retrieval Efficiency ${ }^{14}$

\begin{tabular}{|ll} 
& Retrieval \\
Source Tank & Efficiency \\
AY-102(AP-101) & $90 \%$ \\
AZ-101 & $90 \%$ \\
AZ-102 & $80 \%$ \\
C-Farm Solids/AY-101 & $100 \% / 100 \%$ \\
Continue with HLW solids made available from SST \\
retrieval.
\end{tabular}

\section{A4.4.5. HLW Feed Specifications}

Delivered HLW feed compositions are compared to BNI $\quad$ No contract Specification 8 to assess envelope compliance.

\section{A4.4.6. Feed Compliance Verification}

Compliance Verification Sampling

Allow 210 days to complete feed compliance verification

starting from when each staging tank (DST) is first filled with feed.

\section{A5.0. Project Delivery}

\begin{tabular}{|c|c|c|}
\hline \multicolumn{3}{|c|}{ A5.1. Project Impacts on DST System Availability ${ }^{16}$} \\
\hline AN-101-01A Pit work (W-314) & $6 / 1 / 2001-10 / 1 / 2004$ & No \\
\hline 241-A-A Pit work outage (W-314) & $3 / 1 / 2004-10 / 1 / 2004$ & No \\
\hline AN Farm Outage (W-314) & $6 / 1 / 2004-10 / 1 / 2004$ & No \\
\hline AP Farm Outage (W-314) & $7 / 1 / 2004-10 / 1 / 2004$ & $\overline{\text { No }}$ \\
\hline $\begin{array}{l}\text { Cross-site line outage connects } \\
\text { cross-site to AN farm (W-314) }\end{array}$ & $5 / 15 / 2004-11 / 1 / 2004$ & No \\
\hline Cross-site to AP farm (W-211) & $5 / 15 / 2004-11 / 1 / 2004$ & No \\
\hline AW Farm Outage (W-314) & $7 / 1 / 2004-10 / 1 / 2004$ & No \\
\hline SY Farm Outage (W-314) & $7 / 1 / 2004-10 / 1 / 2004$ & No \\
\hline 244-S Outage (W-314) & $\begin{array}{l}4 / 10 / 2003-1 / 15 / 2004 \\
222-\mathrm{S} \text { direct routed to SY farm after } 6 / 30 / 2005 \\
\text { PFP can no longer use } 244 \text {-TX after } 6 / 30 / 2005\end{array}$ & No \\
\hline AY Farm Electrical Upgrades & $12 / 23 / 2002-12 / 31 / 2003$ & No \\
\hline AZ Farm Electrical Upgrades & $1 / 9 / 2003-12 / 31 / 2003$ & No \\
\hline \multicolumn{3}{|c|}{ A5.2. Feed Staging Tank Upgrades } \\
\hline & $\begin{array}{l}\text { The necessary equipment will be available in time to } \\
\text { support all planned waste transfers. } \\
\text { The DSTs will need a mixer pump, and, a } \\
\text { decant/transfer pump (if solids entrainment is a } \\
\text { concern) or a fixed intake transfer pump (if solids } \\
\text { entrainment is not a problem). } \\
\text { The following DSTs have been identified as } \\
\text { requiring expense or capital project work before use } \\
\text { as feed staging tanks; AN-101, AN-102, AN-103, } \\
\text { AN-104, AN-105, AN-107, AP-101, AP-102, } \\
\text { AP-104, AW-101, AY-101, AY-102, AZ-101, and } \\
\text { AZ-102 }\end{array}$ & No \\
\hline
\end{tabular}


Table A-1. Assumptions Matrix. (19 Sheets)

Case name: Sr Solubility Model Test

Involves Model

Change That

Needs to be

Verified?

A6.0. HTWOS Model or Data Analysis Assumptions

A6.1. Estimating Waste Compositions

Wastes are homogenized when mixed.

No

A6.2. Water Content of Initial Inventory

The water content of initial inventory is determined by

No

calculating a stream density and total stream mass

(including water), the total stream mass excluding water,

and then obtaining water content by difference.

A6.3. Volume of In-Process Streams

Volumes of waste streams are calculated from mass

using density correlations for liquids and a solid density

of $3 \mathrm{~g} / \mathrm{mL}$.

\section{A6.4. Transuranic Content Accounting}

TRU quantities for LAW and ILAW are based on

Specification 2 and 7 definitions.

No

A6.5. Radionuclide Decay

- The BBI reference decay date of $1 / 1 / 2001$ is used as the reference decay date in the model.

- Radionuclides are decayed to the date of delivery for feed specification compliance assessment.

- Half-life values for decay calculations are taken from the Chart of Nuclides, $15^{\text {th }}$ Edition.

A6.6. Waste Chemistry and Mass Balances

\begin{tabular}{|c|c|c|}
\hline & $\begin{array}{l}\text { Dissolution of solids is predicted by the application } \\
\text { of wash factors (or } \mathrm{Sr} \text { model in the case of } \mathrm{Sr} \text { ). } \\
\text { Chemical charges are balanced when washing solids } \\
\text { by the adjustment of bound } \mathrm{OH}^{-} \text {and then by } \\
\text { adjustment of } \mathrm{CO}_{3}^{2-} \text {. } \\
\text { - HTWOS does not account for solids formation, } \\
\text { except for repartioning of Sr using the } \mathrm{Sr} \text { model. }\end{array}$ & Yes \\
\hline \multicolumn{3}{|l|}{ A6.7. ILAW Package Production } \\
\hline 20 & $\begin{array}{l}\text { ILAW package production rates are based on the glass } \\
\text { production rates, glass density, and package fill } \\
\text { assumptions. }\end{array}$ & No \\
\hline \multicolumn{3}{|l|}{ A6.8. IHLW Canister Production } \\
\hline & $\begin{array}{l}\text { IHLW canister production rates are based on the glass } \\
\text { production rates, glass density, and package fill } \\
\text { assumptions. }\end{array}$ & No \\
\hline
\end{tabular}


RPP-21807 Rev. 0

Table A-1. Assumptions Matrix. (19 Sheets)

Case name: Sr Solubility Model Test

Involves Model

Change That

Needs to be

Verified?

\section{A6.9. Mission Summary Diagram}

Mission Summary Diagram

- Schedule float
- Handled external to the model. When possible, No

- Transfer window allocate 6 months float on either side of feed compliance verification activities for the $1^{\text {st }}$ batch of LAW and the $1^{\text {st }}$ batch of HLW. All other schedule float and project strategy will be developed with guidance from Projects.

- Two months

Notes:

$\mathrm{BBI}=$ Best Basis Inventory

BNI $=$ Bechtel National; Inc .

$\mathrm{BNI} / \mathrm{WGI}=$ Bechtel National-Washington Group

DST $=$ Double-Shell Tank

ETF $=$ Effluent Treatment Facility

$\mathrm{FY}=$ fiscal year

HLW $=$ high-level waste

IDF = Integrated Disposal Facility

IHLW $=$ immobilized high-level waste

ILAW = immobilized low-activity waste

IMUST = inactive miscellaneous underground storage tanks

LAW $=$ low-activity waste

LERF $=$ Liquid Effluent Retention Facility

LLW $=$ low-level waste

MSD $=$ Mission Summary Diagram

NCAW $=$ neutralized current acid waste

$\mathrm{NCRW}=$ neutralized cladding removal waste

ORP = U.S. Department of Energy, Office of River Protection

PFP $=$ Plutonium Finishing Plant

PUREX = Plutonium-Uranium Extraction Plant

RL = U.S. Department of Energy, Richland Operations Office

SST $=$ Single-Shell Tank

TPA = Tri-Party Agreement (Hanford Federal Facility Agreement and Consent Order)

TRU $=$ transuranic

TWINS $=$ Tank Waste Information Network System

WSCF $=$ Waste Sampling and Characterization Facility

WESF $=$ Waste Encapsulation and Storage Facility

WRF $=$ Waste Retrieval Facility

WTP $=$ Waste Treatment and Immobilization Plant

$\mathrm{WVRF}=$ waste volume reduction factor 
RPP-21807 Rev. 0

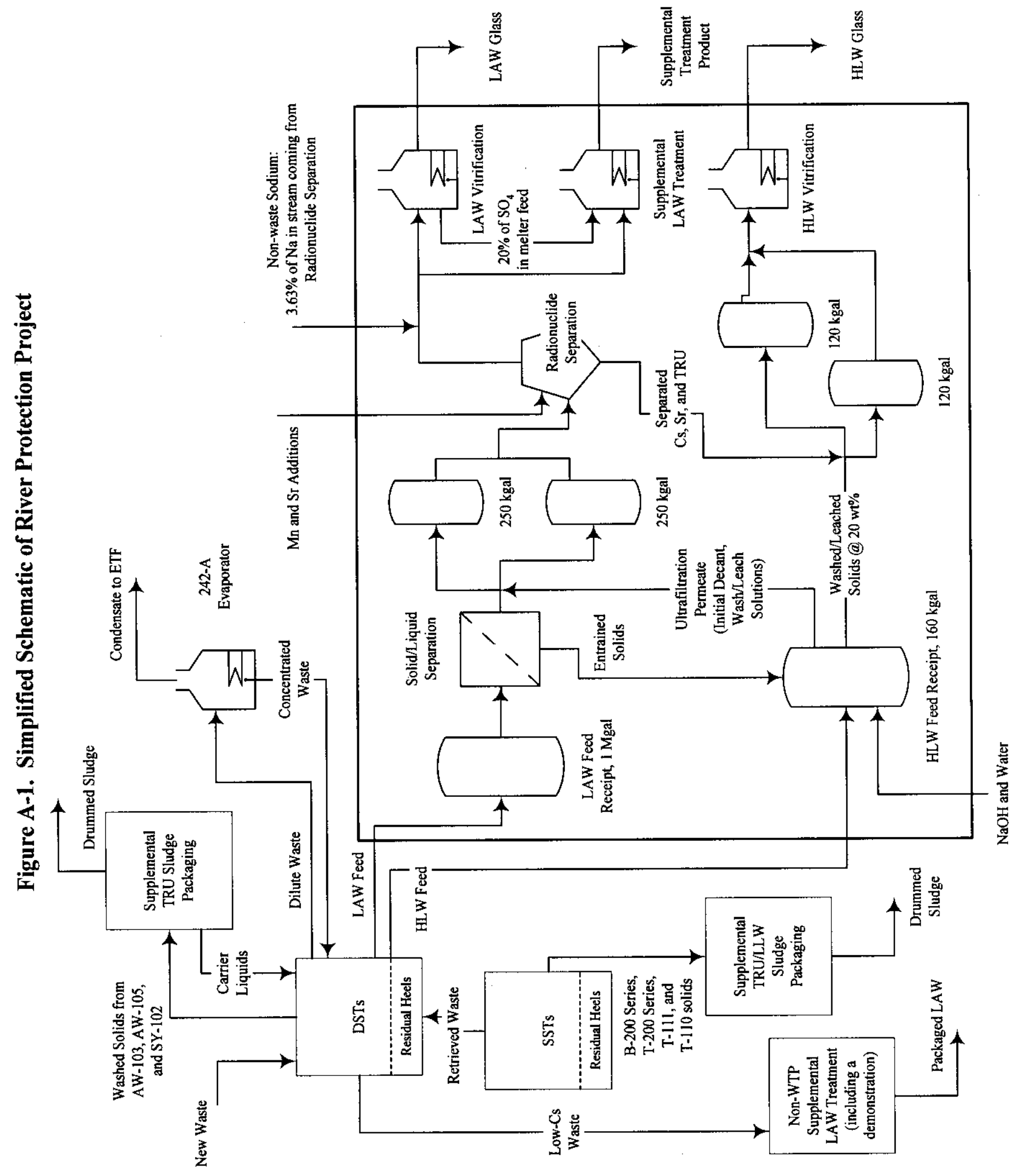


RPP-21807 Rev. 0

Figure A-2. Strontium Concentration to TOC Concentration Correlations.

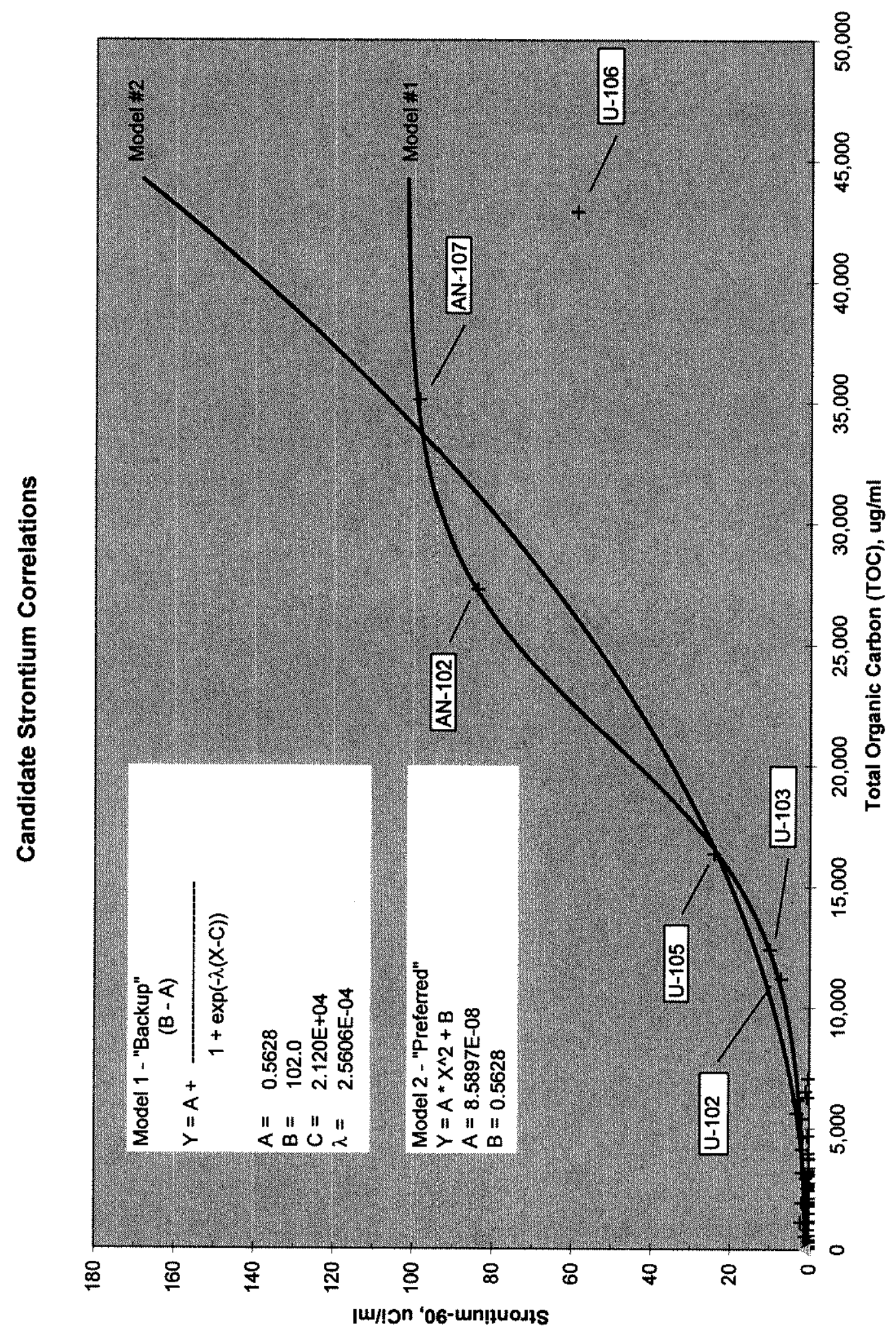


HTWOS Model Modification Form

\section{Modification Title:}

Implementation of a strontium solubility model.

\section{Description of Modification:}

The HTWOS liquid-solid partitioning of Sr-90 was determined from a concentration limit of $C_{\mathrm{Sr}-90}=A C_{\mathrm{TOC}}^{2}+B$, where $A=8.5897 \times 10^{-8}(\mu \mathrm{Ci} / \mathrm{ml}) /(\mu \mathrm{g} / \mathrm{ml})^{2}, B=0.5628$ $\mu \mathrm{Ci} / \mathrm{ml}$ and $C_{\mathrm{TOC}}$ is the TOC concentration. Other $\mathrm{Sr}$ isotopes were assumed to partition with $\mathrm{Sr}-90$ to keep the isotopic fractions in the source phase unchanged.

\section{Method Used to Check Modification:}

A test of the HTWOS calculation was performed by a hand calculation for the $\mathrm{Sr}-90$ concentration for each HLW and LAW feed batch.

\section{Result of Checking Modification:}

Results from the test using HTWOS reported values good to better than four significant figures. In each batch the Sr-90 concentration was less than or equal to the concentration limit within the expected precision.

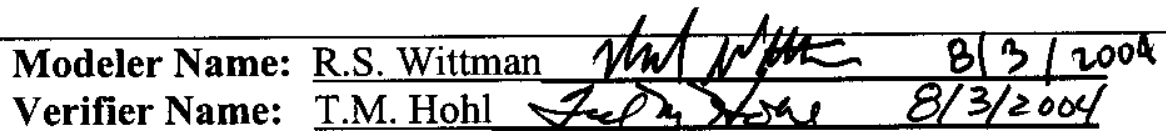

